\title{
Piate XIIX.
}

Fig. 1. The type specimen of Hymeniacidon angulata, Bowerbank, natural size. Fig. 2. A spiculum from one of the fan-shaped groups of the dermal membrane, magnified 150 linear. These spicula vary from the purely spinulate form to the fusiformi-spinulate one of the figure.

Fig. 3. An average-sized ovo-spinulate skeleton-spiculum of about the normal form, magnified 150 linear.

Figs. 4, 5, 6. Varieties of form of the spinulation of the skeleton-spicula, magnified 5:30 linear.

Fig. 7. Represents an adult and fully developed spinulo-multiangulated cylindrical defensive spiculum from the dermal membrane, magnified 660 linear.

May 21, 1872.

Robert Hudson, Esq., F.R.S., V.P. in the Chair.

The Secretary read the following report on the additions to the Society's Menagerie during the month of April 1872.

The total number of registered additions to the Society's Menagerie during the month of April was 131 , of which 10 were by birth, 32 by presentation, 77 by purchase, 2 by exchange, and 10 were received on deposit.

The most remarkable of the acquisitions were :-

1. A Red-bellied Flying Squirrel (Pteromys magnificus, Hodgson : Jerdon, Mamm. of India, p. 177), purchased April 10th, of a soldier, who informed us that he obtained it at Donglee ( $q u$. Tonglee) gulley in the Himalayas. Mr. Berjeau's sketch (Plate L.) will give an idea of the form of this fine species of Pteromys, which is quite new to the collection.

2. A young female Baird's Tapir (Tapirus bairdi), purchased April 15th, having been brought by one of the Society's correspondents from Corinto, on the western coast of Nicaragua.

This animal, although not by any means full-grown, has nearly lost the spots of immaturity which distinguished our former specimen of this interesting species, received in August last*; and as it also differs from the adult as figured by Dr. Gray (P. Z.S. 1867, pl. xliii.), I have thought it advisable to have a careful figure made of it (Plate LI.).

It stands about 23 inches in height, and is 42 inches long, from the extended snout to the rump. Above it is rather thickly covered with brownish-black hairs of about $\frac{3}{4}$ inch in length. The face is rather paler. The ears, except for a portion of their outer rims, are distinctly margined with clear white. The throat and chest are of a sordid white.

The present dentition of this animal consists of six well-developed incisors above, and six below; and two upper canines appear to have

* See P. Z. S. 1871, p. 626, pl. 50. 
recently cut the gum. I could not manage to examine the molars ; but they are certainly present.

The drawing of the ordinary Tapirus terrestris (Plate LII.), which I also exhibit, represents our adult female specimen of this species, purchased July 30, 1869, and still living in the Gardens. It will serve to show the external differences between the two allied species.

3. A pair of Rhinoceros Hornbills (Buceros rhinoceros), purchased April 13th.

The following extracts were read from a letter addressed to the Secretary by Dr. G. Bennett, F.Z.S., dated Sydney, March 21, 1872 :-

"A pair of living Didunculi (said to be male and female) arrived at Sydney on the 6th of February from the Island of Upulu (Samoan or Navigator Islands). One was a fine well-grown bird in excellent plumage; the other was a smaller bird in poor condition, and was probably a younger bird; they were both placed in the aviary of the Botanic Gardens: the latter bird died on the 2nd of March, apparently from an injury of the head accidentally received; I have placed it in spirits for a skeleton. I would have secured and sent both these birds to the Society; but, unfortunately, Broughton in the 'Parramatta' (to whom only I could have intrusted such delicate birds) had sailed early in the morning, on the day of their arrival, so that so desirable an opportunity was lost. At present the surviving bird is in the aviary, in a large wire enclosure together with Nicobar, Wonga, and other Pigeons; it is very lively, in excellent health and plumage, and feeds almost exclusively on yams and hemp-seed, and occasionally amuses itself by chasing and assuming a mastery over the other Pigeons, but does not appear to injure them.

"If a favourable opportunity occurs and the bird survives, I will purchase and send it to the Society. We have in the aviary the Weka (Ocydromus australis), 'Wood Hen' (O. sylvestris), and the New-Caledonian Rail (O. lafresnayanus), ull of whom we find to be excellent rat-catchers, more especially the two former species.

"The Red-billed Curassows (Crax carunculata) have been permitted to roam about the gardens, and eventually built a nest in one of the trees, and hatched two young birds, now seven weeks old (March 10th). They walk about with the mother, feeding upon berries of rarious kinds, and appear very fond of acorns, which are strewed under the English oaks in the gardens; these birds are quite domesticated, and wander about the grounds, not in the least intimidated ty the numerous visitors.

"We have a curious hybrid Pheasant, a cross between the male Reeves's and a female of the Ring-necked Pheasant; it is a large-sized and fine bird, larger than either of the parent birds, and the mottled plumage has a very remarkable appearance.

"A living specimen of the little Penguin (Spheniscus minor) was captured near Sydney, on the 3rd of March; it only survived a few days. These birds are rare so near Sydney." 





告
0
0
0
0
0
0
0
0

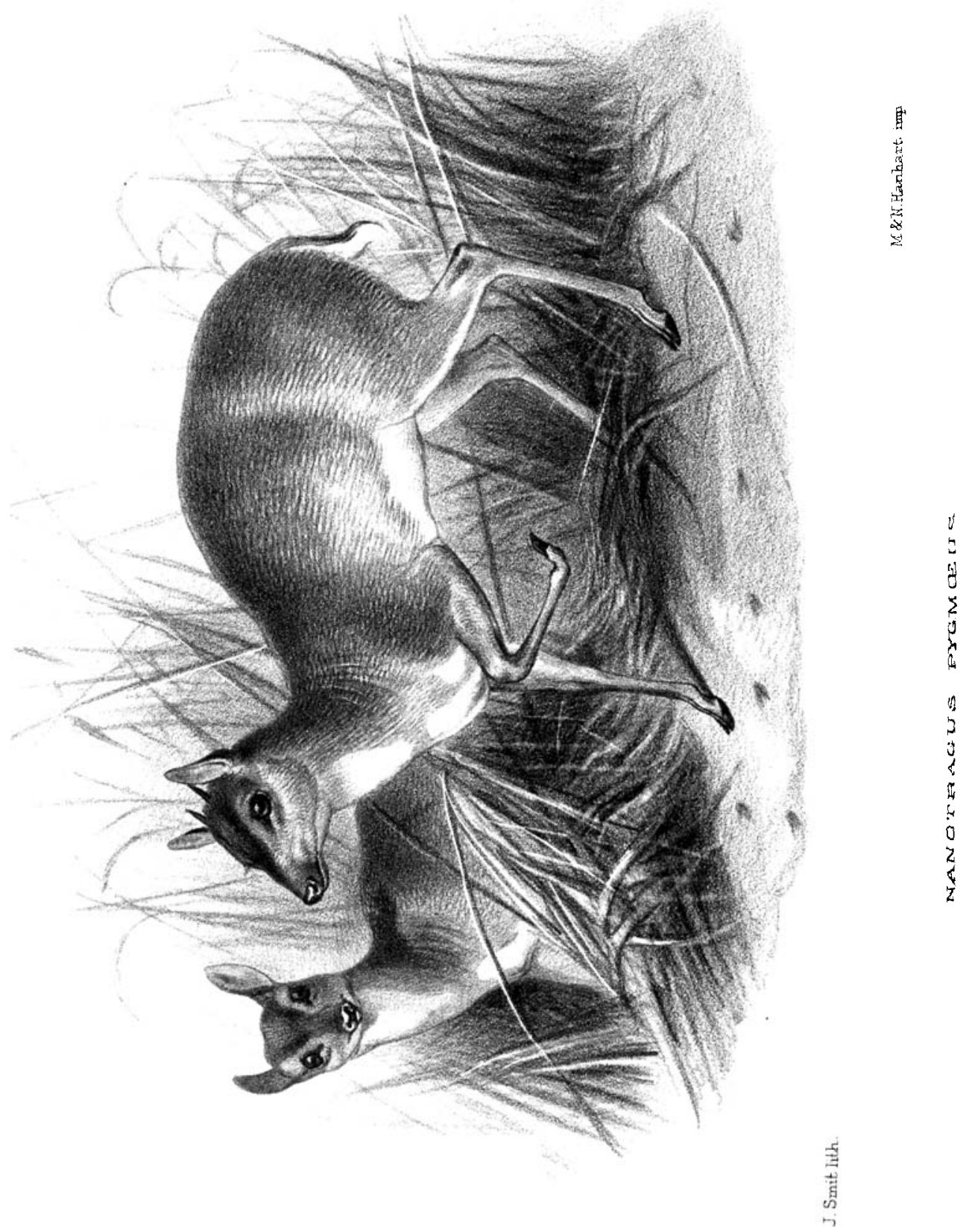


The following papers were read :-

1. On the Royal Antelope, and allied Species of the Genus Nanotragus. By Sir V. Brooke, Bart., F.Z.S.

[Received May 21, 1872.]

(Plate LIII.)

I have the pleasure of exhibiting to the Society three adult and very perfect specimens of Nanotragus pygmaus, the smallest of the Pecora at present known to science. These specimens I received a short time ago from His Excellency Governor Ussher of CapeCoast Castle, West Africa, a gentleman who has already proved himself one of the best friends zoological science possesses in a country still doubtless rich in matters of interest to the naturalist. As regards the nomenclature of this Antelope, the complications and difficulties of its synonymy, extending as it does over a period of upwards of 150 years, equal, and perhaps exceed, those connected with any of the species contained in the extensive group of which it is, as I have said, the smallest representative. But not only is it with respect to its literary history that the species under consideration is involved in some obscurity; partly in consequence of mistakes arising from this source, and partly on account of the paucity of accessible specimens, the natural affinities of the species appear to me to have been somewhat overlooked. I will therefore divide the remarks which I have to offer on this Antelope under two heads, giving first those that concern its synonymy, and secondly those that relate to its natural affinities.

\section{Remarks on the Literary History and Synonymy of Nanotragus pygmæus.}

Professor Sunderall, in his well-known treatise on the Pecora, published in the Swedish Academy's 'Proceedings' for 1847 (p. 303), enters most carefully into an examination of this subject, and, with the exception of one point, seems to have most successfully unravelled the mazes with which it was surrounded. In order to clear up this single point I shall now describe what, after very careful investigation of the matter, I believe to be the history of the species as connected with Linnæus himself, and shall then specify in what respect this account differs from that given by Professor Sundevall.

Bosman, in his travels in Guinea in 1703, so far as I have been able to ascertain, is the first author who mentions the species. At page 249, after describing the colour and very small size of the animal, the feet being made into pipe-stoppers, one of which, he states, he sent home set in gold, Bosman writes, "the negroes here call it the King of Harts :" thus, no doubt, originated the English name of Royal Antelope, by which this species has always been known.

The 'Thesaurus' of Seba, published in 1734, gives us the first substantial record of specimens having found their way into Euro- 
pean museums, figures 1 and 3 of plate 43 and the drawings of feet set in gold being, as I shall endeavour to show presently, undoubtedly referable to the little Royal Antelope. In 1754 the Museum of Adolphus Frederick appears to have contained additional materials for the consideration of Linnæus ; and it is in his catalogue of this collection that he first gives a definite name to the species. As far, therefore, as record serves us, the two chief, probably the only sources from which Linnæus derived his knowledge of the species were, first, the 'Thesaurus' of Seba, with possibly, as Prof. Sundevall suggests, an examination of Seba's collection, and, secondly, the Museum of Adolphus Frederick. In the 2nd edition of the "Systema Naturæ' (1740), six years subsequent to the publication of the "Thesaurus," Linnæus first mentions the species; we there find the diagnosis "Capra pedibus digito humano angustioribus," with reference to plate 43 . fig. 3 of the 'Thesaurus.' In the 6 th edition of the Syst. Nat. (1748), this diagnosis and reference are repeated word for word. In 1754 Linnæus wrote his catalogue of the collection of Adolphus Frederick, and in it gives new information derived from new sources. He describes a specimen in that collection in the following manner (p. 12):- "Feet scarcely thicker than a penholder; colour grizzly; the size of a cat; neck rather ashy; underneath the following parts are white-the tail, throat, abdomen, breast, and inner thighs ; ears ovate and rather naked." To his description he appends the diagnosis which $I$ have given above from the 6 th and 7 th editions of the 'Systema Naturæ,' referring still to Seba's plate 43. figure 3, and proposing for the species the name of Capra perpusilla. In this catalogue, however, at the same page, Linnæus mentions, under the name of Cervus guineensis, a specimen the diagnosis of which in no way agrees with his Capra perpusilla. He thus describes it:- "From Guinea ; of a greyish colour, underneath blackish; size of a cat; a streak between the ears and a spot over the eye black; throat on both sides longitudinally black; chest black in the middle, a dark line running along the flanks as far as the tarsal joint; a blackish line from the anus to the tarsal joints; anterior surface of the fore limbs as far as the carpal joint black, and a narrow black line drawn to the feet; ears rather long; tail underneath black ; tibiæ double as thick as those of the next species" (viz. Capra perpusilla). The existence of these dark markings so carefully described clearly indicate a wide distinction between this specimen and that which supplied the diagnosis of the species immediately following in the catalogue, in which no dark markings are mentioned-the throat and underparts described as black in C. guineensis, being, on the contrary, in $C$. perpusilla described as white. The purity of this colour is, as may be seen in the specimens before the Society, most characteristic of the Royal Antelope. In the 10th edition of the Syst. Nat., published four years after the Catalogue, as is not a little remarkable, Linnæus, regardless of the name Capra perpusilla given in his former publication, gives to the same species the new name of Capra pygmea; nor does he enlarge his diagnosis, merely bringing down 
that of his 2nd and 6th editions. He, however, introduces for the first time in this edition Cervus guineensis of the Catalogue of Adolphus Frederick, with the short diagnosis " $C$. griseus, subtus nigricans." In the 12th edition (1766) we find collected under the name of Moschus pygmaus all the allusions to this species in the early editions of the 'Syst. Nat.,' with still no mention of the collection of the king; but here, for the first time, Linnæus refers figs. 1 and 2 of Seba's plate 43 to this species. The diagnosis of Cervus guineensis is brought down unaltered from the 10th edition.

My interpretation of this complicated and difficult subject is as follows. I believe that two perfectly distinct species were the types of the Moschus pygmaus vel Capra perpusilla and the Cervus guineensis of Linnæus. The type of the former I believe to have been a genuine specimen of the Royal Antelope, which specimen is represented in fig. 3 , plate 43 , of Seba's 'Thesaurus.' The débris of Seba's collection, as Temminck at page 203 of his 'Esquisses Zoologiques' informs us, was received by him at Leiden about 50 years after Seba's death. Amongst the remnants of this collection Temminck discovered a very young specimen of his Nanotragus spiniger, discoloured and hardly recognizable, but still in sufficiently good condition to admit of its being set up and placed in the Leiden collection. From the rarity of specimens, and the exact correspondence of 'Temminck's description of this specimen with fig. 3 of plate 43 of the 'Thesaurus,' it is almost certain that this is the identical specimen represented in the drawing; if so, it is clear that a true specimen of the Royal Antelope was the type of Capra perpusilla of the Catalogue, and therefore of the Moschus pygmoers of the 12th edition of the 'Systema Naturæ.' A consideration of the history of the specimens contained in the collection of Adolphus Frederick throws additional light upon this conclusion. This colleetion, Prof. Sundevall tells at page 304, l. c., passed entire to Stockholm. In a bottle which Prof. Sundevall tells us he failed to examine sufficiently carefully during the preparation of his first treatise in 1844, he found in 1846 a veritable specimen of the Royal Antelope, in size and form so similar to Seba's fig. 1, plate 43, that he could have believed it to have been the type of that figure. In the fact of this undoubted specimen having passed under the investigation of Linnæus we have still further grounds for believing that the species described by him under the name of C. perpusilla in the Catalogue, and of Moschus pygmaus in the 12th edition of the 'Systema Naturæ,' to both of which fig. 3, plate 43, of the 'Thesaurus' is referred, was undoubtedly the species under consideration, the Royal Antelope. The type of Cervus guineensis seems to me to be equally certain. Agreeing in every detail with the description given in the Catalogue we find fig. 2, plate 43 of the 'Thesaurus.' At page 301 Prof. Sundevall expresses his opinion that nothing at all answering to the description of $C$. guineensis was to be found in the Drottingholm collection; but at page 304 he says that in the same bottle as that in which he discovered the young male of Nanotragus spiniger he also discovered a specimen exceedingly 
similar to this very figure; and this figure, as I have said above, resembles in every detail the minute descrip ion given by Linnæus of his Cervus guineensis, the dark belly and n urkings, which are well shown in the drawing, distinguishing it from the two other figures in the same plate (43), one of which (fig. 3) I have endeavoured to show is the type of the Moschus pygmaus of Linnæus. it seems to me clear therefore that the description of $C$. guineensis given at page 12, in the Mus. Adolph. Frid., was founded on this specimen,Linnæus being at the time strengthened in his opinion of the distinctuess of the species by finding two drawings (fig. 2, plate 43 , and fig. 1, plate 44) in Seba's 'Thesaurus' closely resembling the donbtless very immature specimen submitted to his inspection in the king's collection.

It is not, however, so plain what species was represented by Cervus guineensis; indeed I think it would be almost impossible to form any conjecture upon this subject. There is not only the difficulty of selecting amongst the large number of species of Cephalo$p h i$ found on the west coast of A frica; but, at the time Linnæus wrote, vast confusion existed between this group and the two widely distinct groups, the Tragulina and the Moschi. It would therefore, I believe, be impossible to determine to what exact species this diagnosis belongs, bearing as it does strong traces of having been founded on a very immature and imperfect specimen.

There is much that leads me to the conclusion that Linnæus himself became gradually convinced that his diagnosis rested upon insufficient grounds; and I find in his own copy of his 12th edition, preserved in the library of the Linnæan Society, he has drawn his pen through this diagnosis, as if to erase it from his work; and in Gmelin's edition of the 'Syst. Nat.' the species is not mentioned. On the whole, I think the circumstances do not admit of the interpretation deduced from them by Prof. Sundevall, who, at page 301 , expresses his opinion that Cervus guineensis "was founded on some error," and considers it probable that under that name Linnæus described the large specimen of Nanotragus pygmaus which subsequently went to Stockholm with the Drottingholm collection, mixing and comprising with this description "some other notes taken from another source," possibly from Seba's fig. 1, plate 43 , "adding also notes retained in his memory from an examination of Tragulus javanicus."

On the contrary, as I have explained above, I consider $C$. guiveensis to have been founded on a young specimen of some snsall species of Antelope, not now to be ascertained, but clearly dist :..t from the Moschus pygmaus of Linnæus.

Subject to this exception, Professor Sundevall's elaborately workedout synonymy of this species appears perfect; and with this alteration it will stand thus, the eariiest specific name to be adopted being that of Linnæus, in the 12th edition of the "Systema Naturæ":-

Nanotragus pygmeus. (Plate LIII.)

1703. Très-petit Cerf, Bosman, Guinea, pp. 236, 252. 

B.

1734. Cerva parvula (part.), Seba, Thesaurus, pl. 43. figs. 1-3 A,

1740. C. pedibus diyito \&c., Linn. Syst. Nat. 2nd edit.

1754. Capra perpitsilla, Linn. Mus. Adolph. Frid. p. 12.

1758. Capra pygmaa, Linn. Syst. Nat. 10th edit.

1764. Chevrotain (part.), Buff. Hist. Nat. vol. xii. p. 341, pl. 43. figs. 3-6.

1766. Moschus pygmaus, Linn. Syst. Nat. 12 th edit. p. 92.

1767. Antilope pygmaa, Pallas, Spic. Zool. fasc. xii. p. 18.

1771. Royal Antelope, Pennant, Syn. Mamm. pp. 28, 19.

1777. Antilope regia, Erxl. Syst. Règ. An. p. 278.

1781. Royal Antelope, Penn. Hist. Quad. p. 72.

1789. Moschus pygmaeus, Gm. Syst. Nat. i. p. 173.

1806. A. pygmaa, Turt. ed. Syst. Nat. p. 115.

1820. Moschus pygmaus, Desmarest, Mamm. p. 428.

1829. A. pygmaa, Fisch. Syn. p. 469.

1835. Antilope spinigera, 'Temm. Monogr. Mamm. i. p. xxx (desc. nulla).

1844. Nanotragus spiniget, Sund. Pecora, p. 191.

1847. Nanotragus spiniger vel perpusillus, Sund. Pec. App. ii. p. 308.

1850. Nanotragus regius, Gray, Knows. Menag. p. 12.

1850. Nanotragus perpusillus, Gray, P. Z. S. p. 126.

1852. Nanotragus perpusillus, Gray, Cat. Mamm. Brit. Mus. p. 89.

1853. Calotragus spiniger, Temm. Esq. Zool. p. 201.

1855. Antilope spinigera, Wagn. Säugeth. p. 416.

\section{Remarks on the Natural Affinities of N. pygmæus.}

The following important characters connect $N$. pygmaus with seven or eight species which together form a natural group, the value of which appears to me to be substantially not more than generic.

Horns rising immediately above the postorbital process of the frontal bone, and well in front of the fronto-parietal suture, which is nearly straight. Suborbital fossa large, suddenly pressed in before the orbit, and extending forward along the superior maxillary. Anteorbital vacuity present but small. Brain-case considerably prolonged backwards. Auditory bulla large and smooth externally, no septa internally. The portion of the tympanic bone which forms the extr rnal auditory meatus (owing to the large size of the bulla) coils $\mathrm{t}$ ck upon itself with a remarkably shell-like whorl. Paroccipital

cess pressed against the posterior wall of the bulla, a considerable portion of the mastoid being visible externally between the posttympanic process of the squamosal and the paroccipital; basioccipital raised into a low median ridge, with two imperfectly developed anterior tubercles. Nasals of moderate length. Crown of the head smooth; naked portion of the muzzle small. False hoofs small or absent. Duct, or ducts, for the escape of the secretion of the suborbital gland small in comparison with the size of the gland.

Proc. Zool. Soc.-1872, No. XLI. 


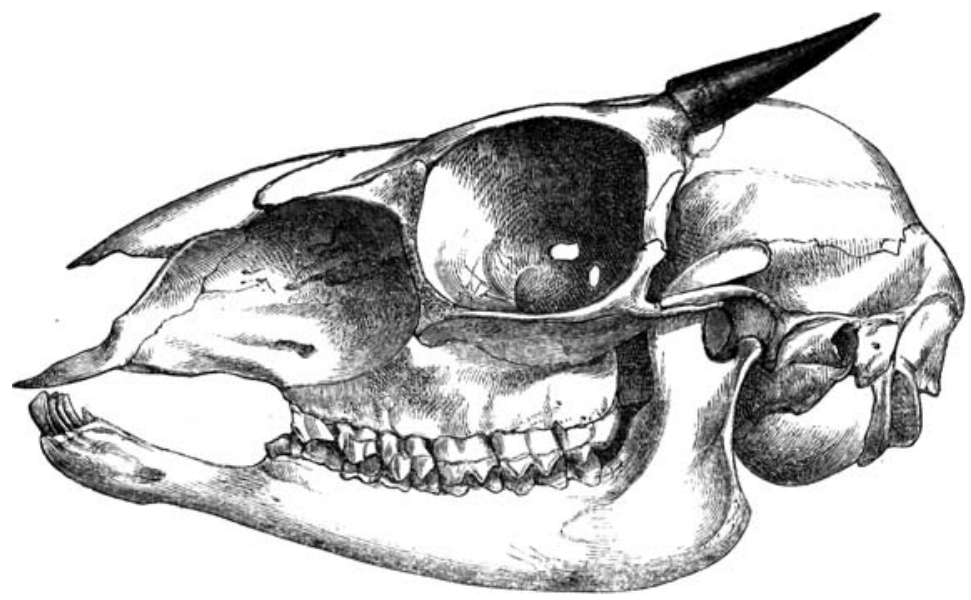

Skull of Nanotragus pygmaus.

These characters are common to the following genera of other authors, which I give below with the dates of their creation:-

1844. Nanotragus, Sund. Vet. Akad. Handl. p. 191. Type $N$. spiniger.

1846. Calotragus, Sund. Vet. Akad. Handl. p. 192. Type $A$. tragulus, Licht. Berl. vi. p. 176 ( 1814 ).

1846. Scopophorus, Gray, Ann. \& Mag. Nat. Hist.p. 232. Type A. scoparia, Schreb.

1846. Nesotragus, Von Düben, Vet. Akad. Efvers. p. 221. Type N. moschatus, Von Düb.

1846. Oreotragus, Gray, Ann. \& Mag. Nat. Hist. p. 231. Type o. saltatrix.

I therefore propose to unite these genera under the common title of Nanotragus, and to regard the minor sections as of subgeneric value only. The groups would then be arranged as follows :-

a. No false hoofs, no knee-brushes. (Nanotragus.)

Nanotragus pygmaus, Linn. Guinea.

- moschatus, V. Düb. Zanzibar, E. Africa.

- tragulus, Licht. S. and E. Africa.

b. False hoofs and knee-brushes present. (Scopophorus.)

Nanotragus scoparia, Schreb. S. Africa.

- montanus, Rüpp. N.E. Africa.

hastatus, Pet. Mozambique.

c. False hoofs present, knee-brushes absent. (Oreotragus.)

Nanotragus melanotis, Thunb. S. Africa.

- oreotragus, Schreb. N. \& S. Africa. 
Very closely allied to this group is the little Antilope saltiana of North-eastern Africa; but for the present, until an opportunity occurs for examining this species alive or in a fresh state, I think it evinces sufficiently important characters to make it safer to leave it in a distinct genus, characterized from Nanotragus by having the crown of the head tufted, muzzle hairy, præmaxillæ long, reaching to the lacrymals, nasal bones very short, mesethmoid strongly ossified. The posterior true molar in the lower jaw possesses but two lobes instead of three, as is the case with all other Pecora. The characters of the nasal region, from their singular resemblance to those of Saiga tatarica, render it probable that these parts will upon examination be found much modified. A well-marked tentorial ridge exteuds along the periotic bone, projecting forward in a prolonged point on each side of the pituitary fossa. From Cephalophus Nanotragus may be distinguished by the following characters peculiar to the former genus :-

Crown of the head tufted. Apertures of the suborbital gland minute, extending in a line along the cheek; muzzle large. Horns placed so far back as to arise from a process of the frontal bone which projects into the parietals. A distinct septa divides the interior of the auditory bulla into two distinct chambers, the posterior of which occupies the part of the bulla posterior to the external auditory meatus. The number of rib-bearing vertebræ in Cephalophus, in all the species of which I have been able to examine the skeletons, is fourteen, whereas thirteen appear characteristic of Nanotragus. Professor Sundevall, in his diagnosis of his genus Nanotragus, denies to the Royal Antelope the possession of suborbital glands. This mistake probably arose from the examination of dried skins, in which, from the exceedingly small size of the apertures of the ducts, the presence of the gland might not be suspected. The accompanying drawing (sce fig. p. 642) and the specimens, however, show this gland to be of enormous size in Nanotragus pygmaus. None of the Cavicornia possessing canines, it may be worthy of remark that the skull of one of the males exhibited shows on one side this tooth in a rudimentary condition. A specimen of Alcelaphus bubalus with a similar growth has passed under my notice.

2. Notes on the Anatomy of the Huia Bird (Heteralocha gouldi). By A. H. Gakrod, B.A., F.Z.S., Prosector to the Society.

[Received May 3, 1872.]

A living specimen of Heteralocha gouldi (Neomorpha gouldi, Gould, B. of Australia, iv. pl. xix.) was obtained by the Society on May 18th, 1870, as was announced by Mr. Sclater in the 'Proceedings,' 1870, p. 383. It died on the 28th of February, 1872, in a much emaciated condition, but without orgauic disease. 
The following notes relate to its anatomy, and may, I trust, assist in enabling its affinities to be more easily determined.

Pterytosis.-The. arrangement of the feathers is completely passerine. The rhombic saddle of the spinal tract does not enclose any ephippial space, therein differing from the Crow's and resembling the typical Starling's. There are nineteen remiges, of which ten are on the hand; they increase in size up to the fifth. The rectrices are twelve in number. The oil-gland is nude.

Tongue.-Simple, horny, one third the length of the beak. It forms a flat elongated triangle, slightly bifid at its apex, and a little prolonged backwards at its lateral borders, enclosing a curved line for the base, the concavity being backwards and carrying retroverted papillæ.

The mucous membrane of the palate extends forward as far as the middle of the tongue; that of the mandible goes a little further.

At the angles of the mouth, just below the eyes, are two yellow oval cutaneous expansions, fixed in front and free at their borders elsewhere; they appear as if they were prolongations outwards of the mucous membrane of the angles of the mouth, which had been reflected backwards-they being continuous in front, round the margins, with the mucous membrane.

Syrinx.-As in Corvus and most of the Old-World Passerines.

Intestines.-The gizzard is well developed. The intestines are 16 inches long, with the bile-ducts $2 \frac{1}{2}$ inches from the gizzard. The cæca are one inch from the cloaca and $\frac{1}{4}$ inch long, being cylindrical.

Arterial System.-There is one carotid artery, the left.

Foot.-The hind toe is slightly longer than the middle anterior toe. In arrangement the tarsal scutes are similar to those of Corvus and most Passerines. Their colour is blue-black.

Skull.-The palate (fig. 2) is strictly ægithognathous; that is, the vomer is truncate in front abruptly, and cleft behind ; the posteroexternal angles of the palatines are produced; the maxillo-palatines are slender, and approach towards but do not unite with one another, nor with the vomer, which they partly embrace. There is no ossification in the nasal septum anterior to the vomer.

The whole cranial configuration (fig. 1) closely resembles that of Sturnus; but the mandible, instead of being bent upwards, is straight. Like it, the palatines are narrow and approximate; the antero-internal angles of the posterior portions of those bones are reduced and rounded off, as is sometimes the case with Sturnus (Mus. Roy. Col. Surg. No. 1539, Ost. Coll.). The romer is completely truncated in front, and is not prolonged forwards at its external angles, as in Corvus and its allies.

The zygoma is not so slender as in Sturnus; but the curves are similar. The articular surfaces on the quadrate bone for the mandible are proportionally very large.

The anterior extremities of the pterygoid bones articulate with the sphenoidal rostrum much as in Corvus, meeting in the middle line behind the posterior extremities of the palatines for a short distance. 



Fig.3
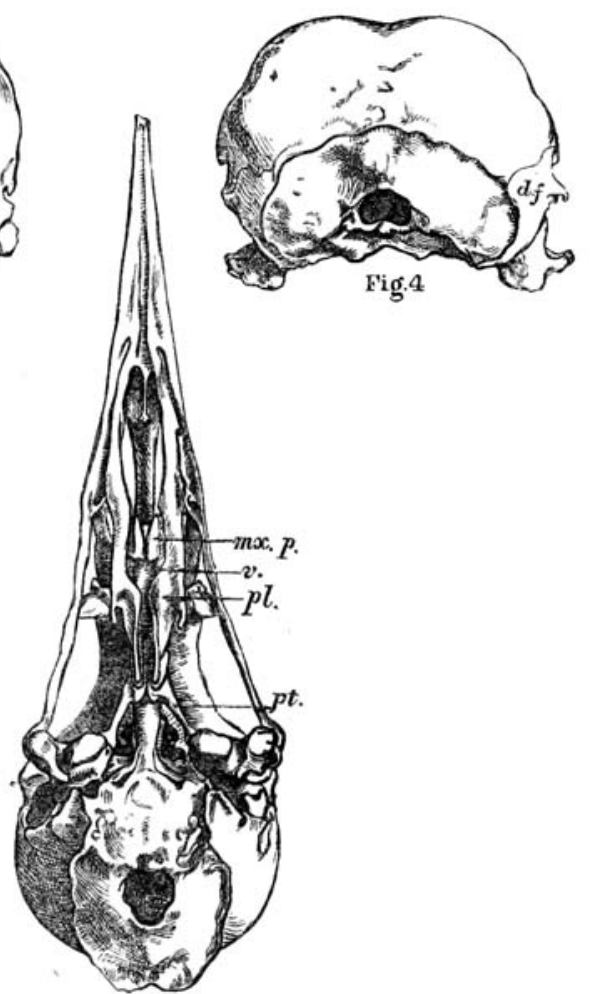

Fig.2

Fig. 1. Skull of Heteralocha gouldi, lateral view.

2. Skull of Heteralocha gouldi, inferior view.

3. Skull of Heteralocha gouldi, posterior view : d.f, digastric fossa.

4. Skull of Corvus frugilegus, posterior view : d.f, digastric fossa. 
The maxillo-palatines in their approximate portions are shorter from before backwards than in Sturnus, and much resemble those of Corvus.

The antero-inferior processes of the orbit are large and spongy; they almost touch the zygoma. But the most characteristic portion of the skull of Heteralocha is the occipital region; and in this it presents a great exaggeration of the peculiarities of Sturnus and its allies.

In Corvus (fig. 4) and most Passerines the digastric muscles occupy a narrow space intervening between the auditory meatus and the mass of occipital muscles, not extending so high up the skull as the latter. The occipital ridge encloses a space elongated from side to side and of but little depth.

In Sturnus the digastrics are much broader, and they narrow the occipital space; they also extend up the skull to so great an extent that they nearly meet in the middle line above the origin of the biventres cervicis muscles; but in Heteralocha (fig. 3 ) they are of still greater size, and meeting above the middle line they form a strong ridge, which extends for some distance into the parietal region vertically. This peculiar development of these muscles produces a corresponding change in the shape of the space enclosed by the occipital ridge. In Heteralocha it is almost circular, and it extends some way above the foramen magnum. In Sturnus there is an approximation to this condition.

A vertical parieto-occipital ridge in many other birds closely resembles that of Heteralocha; but it is the median limit of the temporal fossa in most.

Correlated with this extensive dignstric origin is a large surface for its insertion. The angle of the mandible (see fig. 1, p. 647) is prolonged directly backwards for this purpose, in a manner unique among Passerine birds, but well seen in the Anatida. In Sturnus the angle of the mandible is slightly prolonged backwards for a similar purpose.

In comparing the skulls of others of the Sturnide the following is a graduated series, based on the development of the digastric fossæ in those birds I have had the opportunity of examining, commencing with Heteralocha and ending with Corvus.

Heteralocha.
Sturnella.
Sturnus.
Icterus.
Pastor ialla.
Gracupica.

Quiscalus,
Cassicus.
Acridotheres.
Pastor griseus.
Molothrus.
Corvus.

The palates in most of these birds were not in a fit condition for study; and, as will be clearly seen, geographical range has not been attended to.

In the sternum, Heteralocha differs in no important point from Sturnus, except that the posterior notches tend to be converted into foramina, as observed by Mr. Eyton in his 'Osteologia Avium.' 
The following muscles were dissected, and found to agree precisely with the corresponding ones in a Rook.
Pectoralis major.
Pectoralis minor.
Coraco-brachialis longus.
Coraco-brachialis brevis.
Tensor patagii longus.
Tensor patagii brevis.

\author{
Sartorius. \\ Semimembranosus. \\ Semitendinosus. \\ Adductor magnus. \\ Biceps. \\ Femoro-caudal.
}

In conclusion, it may be stated that the anatomy of Heteralocha shows clearly that it is truly Passerine, and not related to Upupa, as was previously supposed by most authors*. When examined more in detail, its relation to the Sturnida is found to be very intimate, and its structure is clearly not closely allied to that of the Corvida. In its relation to Sturnus it seems to present an exaggeration of the peculiarities of that bird, which would place it at the head of the family.

3. Observations on the Birds of St. Lucia. By the Rev. J. E. Semper, Colonial Chaplain. With Notes by P. L. Sclater.

$$
\text { [Received April 20, 1872.] }
$$

$\mathrm{Mr}$. Semper having kindly sent to me, through our Corresponding Member, Mr. G. W. Des Veux, a second collection of birds from St. Lucia, together with a series of notes on their habits, I have great pleasure in offering to the Society a second communication on this subject, supplementary to that already published in our 'Proceedings' $\dagger$.

I will first give Mr. Semper's notes on the species enumerated in my former list, and then state the additional species contained in the present collection, with Mr. Semper's notes on them.

\section{a. Species contained in former list.}

1. Margarops herminitri, l.s. $c$. p. 268. (Molvie, or Mauvie.)

This bird is counted as one of our game birds, and is killed in large numbers from August to January yearly. About October to December these birds are found in large numbers in flocks feeding on the berries of certain trees ; but for the remainder of the year they are dispersed in pairs, and become very poor. They breed about April or May, the female building a nest of dried leaves, twigs \&c. on a bush or low tree, laying two eggs of a blue-green. They take very little shot to kill them.

* Mr. G. R. Gray has placed Heteralocha in the Sturnida in his 'Hand-list of Birds.'

+ See P. Z. S. 1871, p. 263. 
2. Margarops montanus, l. c. p. 268. (Grivotte or Grevotte.)

This also is counted amongst amongst our game birds. It is in season at the same time and feeds on the same berries as No. l, becoming at the height of the season a mere lump of fat. It is a much more common bird than No. 1 , and it is to be found scattered about the half-cultivated part of the country all the year round. It is an inquisitive bird, standing with head on one side, tail elevated, and wings drooping and trembling, chattering and peering at the passer-by, until it sees signs of danger, when it quickly flies off to a small distance to repeat its motions. They are vigorous birds, and contain a great deal of blood for their size. I have met individuals of this species who have fairly impaled themselves on sharp sticks when flying through the bushes.

\section{Rhamphocinclus brachyurus, l. c. p. 268. (Gorge- blanc.)}

This bird seems to be strictly insectirorous. It is constantly to be met with in pairs, or in small mobs of four or five pairs, busily searching amongst the bushes near the ground and in low trees.

I have seldom observed it at any great height, nor does it seem to indulge in long flights. It is an inquisitive noisy bird, and, on seeing any thing larger than itself passing by, will stand head and tail elevated, wings drooping, and with open mouth keep up a constant warning chatter, and throwing itself about in all sorts of contortions. When a mob of them act thus together, as they often do, the scene is an amusing one to the passer-by, and useful, as it often indicates the presence of a snake or of game.

4. Cinclocerthia macrorhyncha, l.c. p. 268. (Le Trembleur.)

Another insectivorous bird, constantly at work creeping about the trunks and larger limbs of trees searching for its food. They are generally met with in pairs. The bird obtains the name of " $L e$ Trembleur" from its constant quivering and shaking, as though suffering from an ague-fit. About March and April I have heard individuals of this species, I suppose males, give utterance to a lively and pleasing song, extending to some three notes on the scale ; at other times they are silent, with the exception of a callnote to each other, and a scream or warning cry when hurt or frightened.

\section{Mrmus girvus, l. c. p. 268. (Grieve blanc.)}

This bird is said to be a recent immigrant into St. Lucia, where, however, it is now plentiful; it keeps to the open ground near roads and cleared lands, generally seen in pairs. Their song, though not very pleasant, is varied; and they seem often to be trying to imitate the cries and notes of other birds. I have never met with it in the woods. 
6. Dendreca adelatde, $l$. c. p. 269. (Sucrier gran-bois.)

A rather shy little bird, generally found in pairs in the underbrush busily searching about, apparently for insects.

7. Vireosyluia calidris, l. c. p. 269. (Mabelle.)

A berry-eater, found scattered about in pairs.

8. Certhiola martinicana, $l$. c. p. 269. (Sucrière.)

A fruit-eater, found throughout the island, generally in pairs; there is little, if any, outward and striking difference between the sexes. It is far from being shy of man, as it will come into the house to sip water or plunder fruit \&c., and is often to be met with in the sugar-houses, regaling itself on the sweets there. It has a pleasing little song, though feeble and of little compass. I have often seen it in my gallery sipping honey, or catching insects from the flowers there, or bathing in the dog's water-dish, and tantalizing the cat, who can seldom manage to catch one, they being active and wary as well as bold.

9. Myiadestes genibarbis, $l$. c. p. 269. (Sifleur montaigne.)

Generally found in the virgin forest or near it, a shy retired bird, more often heard than seen; they do not seem to pair rery strictly. Their note is a succession of whistles, three short and full, in rapid succession, followed after a short interval by a long sustained note a semitone higher, dying away into silence. In the woods, when several of them are about, they seem to be calling out to each other at a distance, and answering on all hands, so that the collector is often at a loss which bird to follow; by imitating their note, however, with a little patience, they generally can be induced to show themselves. Their food seems to be principally small snails; at least I have generally found such in their throats or crops. They are fond of cool shady places on the hills and high lands.

\section{Saltator guadelupensis, $l$. c. p. 270. (Grosbec.)}

Much hated by the labourers, as it has the reputation of being very destructive to the pigeon- or Angola-pea.

\section{Loxigilla noctis, $l$. c. p. 270. (Père-noir.)}

The female of this bird is totally distinct in colour from the male, she being of an almost uniform green, whilst be is black, with a crimson gorget. They are generally met with in pairs, and have the reputation of being destructive to sugar-canes. It is said the bird will dig out a small hole in a cane, so as to get at the soft sweet pith, and this wound destroys the cane.

12. ICtFRUS LAUdABILIS *, $l$. c. p. 270 .

Another reputed sugar-cane destroyer. Very little if any differ-

* In the present collection Mr. Semper sends a specimen of what he calls the

"Dusky Carrouge," with the following note:-

"The only one of the kind I have seen. At first I took it to be a young bird 
ence observed between the male and female; they generally keep in pairs, though sometimes small mobs of eight or ten may be seen. Birds of the first year have merely a foreshadowing of the beautiful plumage of the older birds.

Their nest is said to be formed by fastening together the two sides of a leaf of the banana, and then building on this foundation.

\section{Quiscalus lugubris, l. c. p. 271. (Merle.)}

The commonest bird in St. Lucia-that is to say, in the cultivated and inhabited parts of it. This bird is seldom or never seen but in the neighbourhood of cultivation. It is a sort of general scavenger, eating any thing that comes to hand. The male is of a rich glossy bluish black, the female of a sombre brown; the birds of under one year resemble the adult hens. They pair, but not strictly, and during the day are scattered about foraging; towards evening small companies of them may be seen making for a general sleeping-rendezvous in a tall tree, or cluster of small trees (they seem to prefer the cabbage-palm for the purpose), where several hundreds will meet to roost. About sunset, or a little after, the whole assemblage keeps up a chirping and chattering for some minutes, during which time stragglers may be seen hastening to join the assemblage ; just about daybreak the same musical entertainment is repeated, after which the assembly disperses for the daily search for food, \&c. The people here say that the Merles thus hold their morning and evening prayers.

These birds build a large nest of vegetable fibres, leaves of canes and grasses, on some large bushy tree, numbers on the same tree. April and May is the season for breeding with them, as, indeed, it is for most of the birds here. The male Merle during its flight, and at times when courting, carries his tail in a very peculiar manner, forming an angle with the body, either to right or left; and a cross section of the tail then forms a wedge or angle, so that at first sight the tail seems to be out of joint and injured.

14. Elainea martinica, $l$. c. p. 27 l.

Not recognized. Country name not given.

15. Myiarchus latirostris, l. c. p. 271. (Gobemouche solitaire.)

Met with in quiet cool shady places in the woods.

\section{Myiarchus erythrocercus, l. c. p. 271. (Pipperie Gran-bois.)}

Generally found in pairs in the woods.

of Icterus laudabilis, but, on preparing it for stuffing, found in its ovary a fully developed egg. This specimen was obtained at Micond, on the east coast of the island ; and the bird is said to be common enough there."

On examining this specimen carefully I have come to the conclusion that it is merely a young female of Icterus laudabilis breeding in immature plumage. This is, we know, the case in many species in which the sexes, when perfectly adult, are alike in plumage.-P. L.S. 
17. Tyrannus rostratus, $l$. c. p. 272. (Pipperie.)

Takes its uame from its cry, which somewhat resembles it. The Pipperie affects open land, also the undergrowth or rustrojo which springs up in abandoned clcarings. Its favourite position is perched on an elevated dry twig, whence it makes frequent swoops after insects.

18. Eulampis jugularis, l. c. p. 272 . (Bronze-winged Humming-bird.)

The largest of our Humming-birds; no difference observed between the appearance of the sexes.

19. Eulampis holosirnicus, l.c. p. 272. (Emerald IIummingbir.d.)

Builds a nest of vegetable down, moss and lichens, on any greyishbarked branch or twig.

20. Orthorhynchus ornatus, l.c.p. 272. (Gold-headed II umming-birrl.)

A lively fearless little fellow, will come within a yard of a quict spectator to snck honey \&c. from flowers, or to sip water. When at rest, often elevates his golden crest, which then, however, appears to less advantage than when it is kept flat; when elevated, the crest looks like a number of large pins in a pincushion; but when flat, and in a favourable position, the crest looks like a button of polished gold. During its flight, or when hovering about a flower, the effect is very pretty, as the golden appearance of the crest is presented or withdrawn with every change of the bird's position. 'The female is a trifle smaller than the male, and duller in colour. She builds a nest of vegetable down close down in a cluster of leaves, so that it is seldom seen. When sitting she is very bold, and will dart at the face of an intruder. I have never known her actually to strike; but she wili come within a comple of inches of one's face. All these lumming-birds possess extraordinary powers of flight. Besides their hovering and ordinary mode, they have a flight when alarmed of extreme rapidity, so rapid that the eye can scarcely follow them.

21. Crotophaga ani, l.c. J. 273. (Merle Corbeau.)

The Merle Corbeau, or Keel-bill, of which I forwarded a couple of specimens, is rather a recent immigrant to St. Lncia. It is insectivorous, and keeps together in small tlocks. In 'Trinidad and Demerara, where they are more plentiful, they may be seen perched on the back of cows and mules in the pastures, picking off the ticks \&c. In Demerara they are called "Old Witches."

\section{Coccyzus minor, l. c. p. 273. (Coucon manioc.)}

Found everywhere, but sparingly and singly; always busy hunting among the trees and bushes, creeping, as it were, amongst the branches; is generally noisy just before and during rainy weather ; is a somewhat stupid bird, and does not think of avoiling danger. 
23. Tinnunculus sparverius, $l$. c. p. 273. (Gret-gru Falaise.)

This little Hawk is very useful as an insect- (cricket and grasshoppers \&c.) destroyer; it is known sometimes to make a dash at a chicken, is a very bold bird, will soon become tame enough to feed; it then greedily eats small lizards \&c. These birds possess considerable power of flight, going at times to a great height, and circling about for a long time. I have seen them hovering, perfectly motionless, for several minutes at a time in the teeth of a very stiff breeze, then suddenly swoop and carry off some small animal or grasshopper so rapidly that their motions could hardly be followed.

\section{Butorides virescens, l. c. p. 273. (Caylie.)}

Generally found wading in the shallow stony parts of our rivers; towards evening may often be seen in the pastures, especially in wet weather. When disturbed it flies for concealment to some tree overgrown with lianes, and soon hides itself, which it does very cleverly.

\section{Nycticorax violaceus, $l$. c. p. 273. (Crabier.) '}

Much valued by the sportsman as a game-bird. Keeps hidden in the woods during the daytime, and towards evening comes down to the sea-coast and the open parts of the rivers, to seek its food, which seems to be principally crabs.

\section{b. Species new to the list.}

The second collection forwarded by Mr. Semper contains examples of the following six species, which were not included in the first. I append Mr. Semper's remarks upon each of them.

\section{Antrostomus rutilus, Burm.}

I cannot distinguish the single skin sent of this species from the corresponding sex of $A$. rutilus (vide P. Z. S. 1866, pp. 136, 586). Mr. Semper gives its vernacular name as the "Cent coups de Couteau," under which it is also figured in Lieut. Tyler's drawings. See P. Z. S. 1871, p. 266.

"A night bird, builds on the ground, or rather lays and batches there ; during the day they nestle in pairs on the ground in quiet outof-the-way places; but at night, during March to June, they disperse; and their cry, 'Cent coups de Couteau,' rapidly pronounced, is to be heard in all directions in those places which they affect. From June to March they are seldom heard in the open, and it is supposed they retire into the interior of the island. (By 'open' is meant the cultivated part of the island, generally near the sea.)"-J. E. S.

2. Ceryle alcyon (Linn.) : Sharpe, Kingfishers, pl. 79.

" The 'Pie,' or 'Kingfisher,' is to be found in pairs from Decem- 
ber to April on our sea-coast and by the mouths of rivers. They fish both in salt and fresh water, are very shy and wary birds." J. E. S.

3. Chamerelia trochila, Bp. Consp. ii. p. 77.

Prince Bonaparte has given this name to the Martinican form of C. passerina, with which we may suppose the St.-Lucian form will agree; but $I$ am very doubtful about its real distinctness, although it is upheld by Messrs. Newton (Ibis, 1859, p. 253).

"The 'Ortolan,' or Ground-dove, is found everywhere, but prefers sparsely bushed tracts of ground, the roads and cultivated lands, especially when these have been recently burned off. They keep together in pairs, sometimes many pairs together, feeding during the morning and afternoon, and generally retiring during the heat of the day to cool shady places. Though small they are very delicate eating."-J. E. S.

4. Porphyrio martinicus (Linn.): Scl. et Salv. P. Z. S. 1868 , p. 459.

“' The 'Poule d'Eau,' Coot or Waterfowl, frequents grassy spots near fresh water, is a great plantain- and banana-eater, and consequently in bad odour with the labourers who grow these fruits. The young, with the help of their undeveloped wings, climb up the mother's legs, and nestle under the feathers there. They are active and vigorous as soon as hatched. Very noisy birds in wet weather; very shy and wary, and not very plentiful."-J. E. S.

5. Tringoides macularius.

"The 'Tivi-Tivi' is found solitary or in pairs almost all the year round on the sea-beach or by the river-sides."-J. E. S.

6. Phä̈thon exthereus, Linn.

"'This Tropic-bird breeds on some of the small islets of St. Lucia. It is known also as 'The Boatswain' and 'The Wobbler." J. E. S.

4. On the Sea-bear of New Zealand (Arctocephalus cinereus) and the North-Australian Sea-bear (Gypsophoca tropicalis). By Dr. J. E. GraY, F.R.S. \&c.

[Received April 23, 1872.]

The southern Sea-bear was observed in' Cloudy Bay, in 1773, in Cook's second voyage, where an account of it is given.

Several beautiful drawings of the animal were made for Sir Joseph Banks, which are now with the rest of his drawings in the Botanical Department in the British Museum. Dr. J. R. Forster wrote a description of the animal, which was published by the Berlin Academy 
in an octavo volume under the title of 'Forster's Descriptio Animalium' (p. 64).

Forster sent copies of the figures and notes of the animal to Buffon, which were engraved and the notes published in the sixth volume of the 'Supplement' of his 'Natural History' (p. 336, tab. xlvii.) under the name Ours marin, under which name Buffon combined the Arctic and Antarctic Sea-bears, or Ours marin.

Lesson, in his compilation on Seals, called the species Otaria forsteri (Diction. Class. d'Hist. Nat. vol. xiii. p. 421); and Fischer notices it in his 'Synopsis' as Phoca forsteri (p. 250), and, curiously enough, adds, "Annon potius generi Enhydris adnumeranda?"

Not being able to see any specimen or skull of this species so that I could identify it with my species in the British Museum, and Forster's description of the skull and teeth only showing that it was a species of Arctocephalus, I recorded it under the name Arctocephalus forsteri in the 'Annals and Magazine of Natural History,' for 1868 (i. p. 219), and in the 'Supplement to the Catalogue of Seals and Whales,' published in 1871 .

Dr. Hector, after my repeated inquiry for the New-Zealand Seabear, was so fortunate as to kill several specimens of this animal, and has most kindly sent to the British Museum an adult skull of those which he had procured. He observes in a letter which I have just received:- "I have since received another skull from the Auckland Islands [the most southern island of the New-Zealand group], of a very young individual; the characters are all the same, except that the palate is not so much contracted posteriorly; but the form and position of the posterior aperture is maintained; in my paper as published in our 'Transactions' [of the New Zealand Institute] I have suggested that the head (skull) is $A$. cinereus." He has since sent me two plates, one giving three views of the adult skull, and three of what he calls the very young skull. One is an Arctocephalus, and the other a Gypsophoca.

I have compared the adult skull sent by Dr. Hector with the figure of the skull of the adult male in Quoy and Gaimard's 'Voyage de l'Astrolabe,' 1824, tab. 13. figs. 1 and 2; and I believe that they represent the same species, though there is a slight difference in the position of the grinders as compared with the skull, which has the front edge of the fourth grinder even with the back part of the large aperture in front of the zygomatic arch, whilst in the figure the front edge of the fifth grinder appears to be in this situation; but this may only be a want of accuracy on the part of the artist. I have little doubt that Quoy's animal from Port Western and the New-Zealand one are the same; but it is a matter of doubt if the animal figured by Quoy is the Otaria cinerea of Desmarest's 'Mammalia,' pp. 25l, 348, from Péron and Lesueur's 'Voyage,' tab. ii. p. 75, who received it from Kangaroo Island; for I am not aware that Péron brought home any specimen. It is certainly not the same as $\mathrm{Arc}$ tocephalus (Gypsophoca) cinerea in the British-Museum catalogue, described from Mr. Macgillivray's specimens.

The New-Zealand skull is very like the skull of the Southeru Fur- 
Seal (Arctocephalus nigrescens) from the Falkland Islands and the south-west coast of Patagonia. It differs in the position and form of the grinders, and in the form of the palate, and its contracted sides and truncated hinder part; it differs considerably from it in the outline and prominence of the temporal bullæ and the os petrosa. The upper surfaces are very much alike, and the orbits are very large and of the same size. The lower jaws are very similar; but the callosity of the Falkland-Island specimen is rather longer, and the crown of the teeth is longer and rather more slender-the crown of the NewZealand specimen being as long as broad, that of the Falkland-Island specimen being one third longer than broad.

The upper cutting-tecth in the New-Zealand species appear to form a much narrower series; in the nearly adult specimen, with the bones of the skull not quite knit, from the Falkland Islands, the series of upper cutting-teeth is rather wider; in the skull from the Falkland Islands very like the adult skull from New Zealand, it is half as wide again. Quoy's figure of the cutting-teeth agrees with the skull sent by Dr. Hector.

Mr. Allen suggests that all the Sea-bears of the Southern Ocean are of one species; but he does not appear to have seen specimens of skulls of any of them. If he had, at any rate he would have allowed that there were two. I think that the skulls in the British Museum show that there are three, which may be thus divided :-

* Hinder opening of palate narrow, half-ovate in front. Upper cutting-teeth moderate.

1. Arctocephalus antarcticus, Gray, Suppl. Cat. Seals and Whales, p. 17.

\section{** Hinder opening of palate truncated in front.}

2. Arctocephalus nigrescens, Gray, l.c.p. 20. Upper cutting-teeth large, in a wide series.

3. Arctocephalus cinereus, Gray, l. c. p. 24. Upper cutting-teeth compressed, forming a narrower series.

These skulls sometimes have the back of the palate more or less imperfect, and with a triangular notch or slit in the front edge.

It is curious, after Steller's and Forster's description of the Seabear, that they should be regarded as Seals; it is evident that Fischer observed their un-Seal-like characters when he inquired if they should not be arranged with Enhydris; yet Quoy and Gaimard figure the two species of this genus which they observed with elongate bodies and in the attitude of the common Seals (Phocida). And Gould did the sume with the Australian species; I believe he had never seen the specimen alive.

\section{Arctocephalus cinereus.}

Sea-bear, Cook's Second Voyage.

Phoca ursina, John R. Forster, Descriptio Animalium, p. 64. 
Fig. 1 .



Arctocephalus nigrescens. Falkland Islands.

Fig. 2.

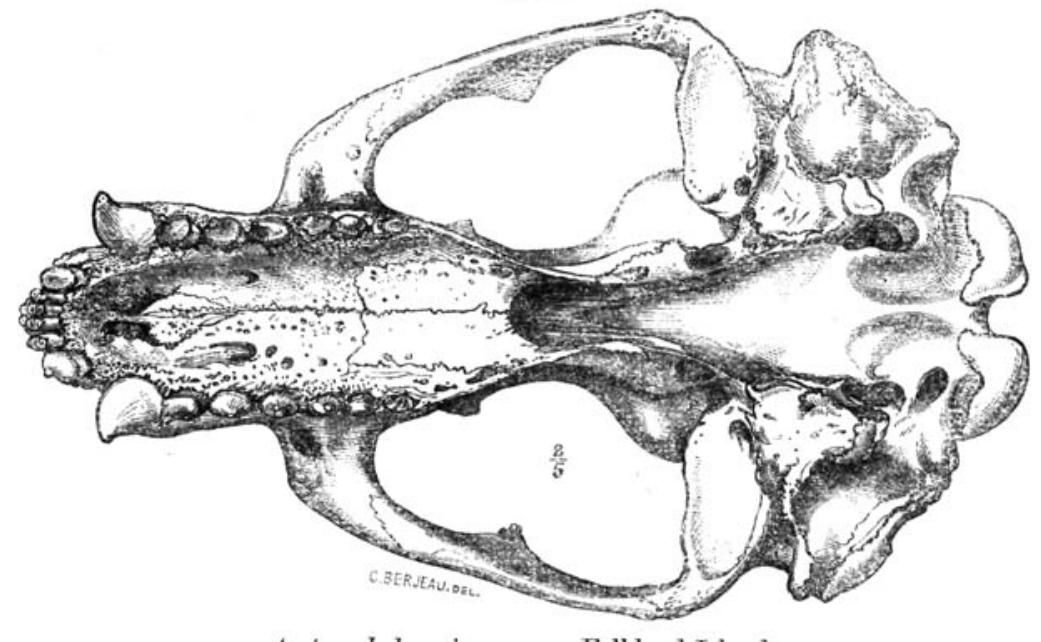

Arctocephalus nigrescens. Falkland Islands.

Ours marin, Buffon, Hist. Nat. Suppl. vi. p. 336, t. 47.

Otaria cinerea, Péron, Voy. Terr. Austr. ii. pp. $54 \%, 77$; Desmarest, Mamm. p. 251; Quoy et Gaim. Voy. de l'Astrolabe, Mamm. p. 89, t. 12, 13, \& 15; Peters, Monatsb. May 17, 1866, p. 272.

Phoca cinerea, Fischer, Synopsis, p. 233. 
Fig. 3.

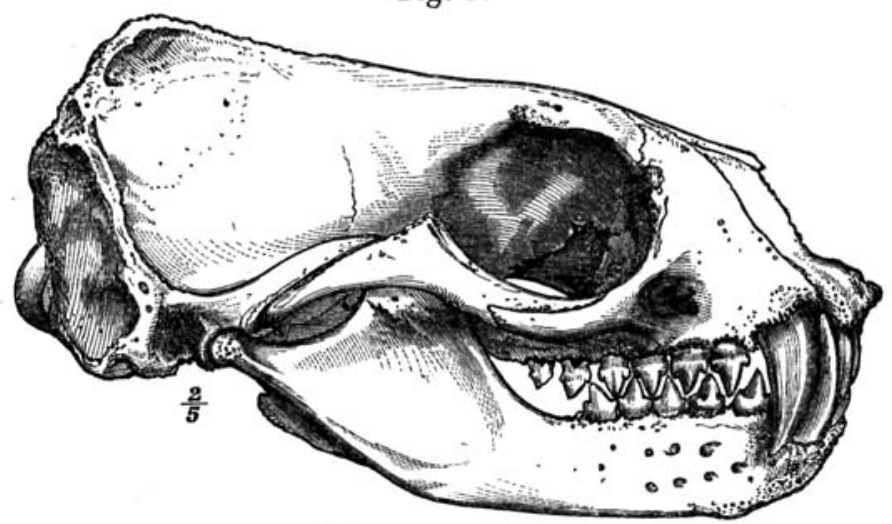

Arctocephalus cinereus. New Zealand.

Fig. 4.

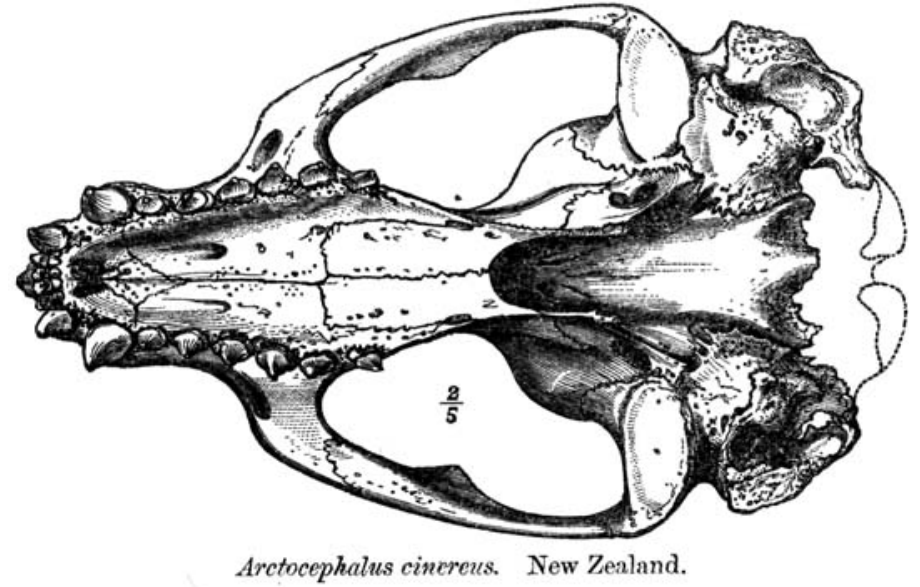

Otarie (Ours du M. Gaimard), Cuvier, Oss. Foss. v. p. 222.

Otaria lamarii, J. Müller, Monatsb. p. 334.

Otaria ursina, Nilsson, Monogr. p. 332.

Otaria forsteri, Lesson, in Dict. Class. xiii. p. 421.

Phoca forsteri, Fischer, Synopsis, p. 333.

Arctocephalus forsteri, Gray, Suppl. Cat. Seals and Whales, p. 25. 671.

Otaria (Arctocephalus) cinereus, Peters, Monatsb. 1866, pp. 272,

Arctocephalus cinereus, Allen, Bull. Mus. Comp. Anat. ii. p. 45 ? (not Gray, Suppl.); Hector, New-Zeal. Institute, iv. t. xii. fig. 1, p. 196 (skull).

Proc. Zool. Soc.-1872, No. XLII. 
Hab. Port Western, N. H. (Quoy); Dusky Bay, New Zealand (Forster).

The skull which Dr. Hector sent from New Zealand is a true Arctocephalus, belonging to the section Euotaria of my Supplement to the Catalogue of Seals, and is quite distinct from the specimens of the skulls which the Museum received from Mr. John Macgillivray as coming from North Australia, which form my subgenus Gypsophocaindeed, so distinct, that I must consider Gypsophoca a distinct genus, more allied to Phocarctos than to Arctocephalus.

The study of the skull would reduce the tribe Arctocephalina, as characterized in the "Supplement to the Catalogue of Seals and Whales' (1871, p. 11), into two divisions, thus :-

* Grinders, two (ffth and sixth) hinder upper quite behind the hinder edge of the zygomatic arch.

1. Procarctos. Skull elongate, front part much longer than twice the length of the hinder part of the skull to the condyle. Palate very deep, much wider in the middle. Under-fur sparse.

2. Gypsopнoca. Skull broad behind, tapering in front; the front part one third longer from the condyle than from the condyle to the occiput. Palate narrow. Under-fur abundant.

\section{** Grinders, the hinder one (or sixth) quite behind the hinder edge} of the zygomatic arch.

\section{Arctocephalus. Under-fur abundant.}

The first, second, third, and fourth upper grinders have an undivided root, whereas the fifth in the upper jaw has the root more or less divided, which in the fifth and sixth is well divided; but the distinctness of the division of the roots of the grinders appears to depend on the growth of the animal. The position of the grinders in the small skulls may be observed before the bones are united together at the sutures. The milk-teeth of the Seals and the Sea-bears are changed very soon after birth, and these animals have a complete series of the permanent teeth when only a few weeks old. The teeth become larger as the jaw grows in size, but they retain their original position with regard to the parts of the bones of the face and the zygomatic arch.

Their position affords an excellent character for the distinction of the species and division of them into groups. Allen, in his plates of the northern Sea-bear (Callorhinus ursinus), figures the skull and teeth of two adult animals and the skull of one only thirty-five days old-the latter showing the teeth exactly placed as in the figures of the two adult specimens. These skulls also exhibit the varieties that exist in the form of the hinder opening to the nostrils of the same species, the chief difference arising in the more or less imperfect manner in which the hinder margin of the palate is developed.

1. The Sea-lions (Otaria) have the palate produced to a line even 
with the condyle. They have only six grinders in the upper jaw, and the last is placed even with the hinder edge of the zygoma.

2. The Sea-bears have the front angle of the hinder nasal opening in the middle of the zygomatic arch.

* Callorhinus, Phocarctos, and Gypsophoca have six grinders in the upper jaw ; and the two hinder grinders are on a level with, or behind, the hinder edge of the zygomatic arch.

** Arctocephalus has six grinders in the upper jaw, and only the hinder one is behind the hinder edge of the front part of the zygomatic arch.

*** Eumetopias has five grinders in the upper jaw; the fifth is far away from the rest and behind the hinder edge of the front part of the zygomatic arch, with a pit between the fourth and fifth as if a tooth were absent; but it is so in all the specimens $I$ bave seen, and Mr. Allen figures it with this peculiarity.

**** Zalophina and Neophoca have only tive grinders in the upper jaw, the fifth grinder being opposite the middle of the front end of the broad zygomatic arch.

\section{Gypsophoca.}

Skull broad behind, at the part behind the ear-hole; the palate narrow, concave ; the internal nostrils rounded in front, and diverging on the sides behind. Grinders $\frac{6}{5} \cdot \frac{6}{5}$, the two hinder upper with two roots, quite behind the hinder edge of the zygomatic arch; the fifth lower fitting between the fourth and fifth upper grinders; the crown of the grinders triangular, elongate, recurved; the upper with a slight denticle in front of the base, the two hinder smooth; the lower ones with a notch on each side.

Arctocephalus, *** Gypsophoca, Gray, Suppl. Cat. Seals and Whales, p. 24.

This genus is most like Arctophoca in the position of the teeth ; but the palate is much narrower, the face short, and the hinder part of the skull much larger and more ventricose. It differs from Arctocephalus in the position of the upper grinders, the narrowness of the palate, \&c.

\section{Gypsophoca tropicalis.}

Black, grey beneath; under.fur abundant, reddish brown.

Arctocephalus nigrescens, b \& c, Gerrard, Cat. Bones B.M. p. 147. Arctocephalus cinereus, Gray, Cat. Seals and Whales, p. 56 ; Am.

\& Mag. Nat. Hist. 1866, xviii. p. 236 (not synonyma) ; Hector, Trans. New Zealand Instit. iv. t. xii. f. 2, p. 196.

Otaria stelleri, Schlegel, Fauna Japonica, tab. xxii, tigs. 5 \& 6 (skull)?

Hal. North coast of Australia (Mr. John Mucgillivray). 
There are adult and young specimens of this species, a perfect skull of a young individual, and the nose, palate, and upper jaw of this species in the British Museum.

The small skull figured by Temminck seems more to resemble this species than Arctocephalus cinereus.

Fig. 5 .

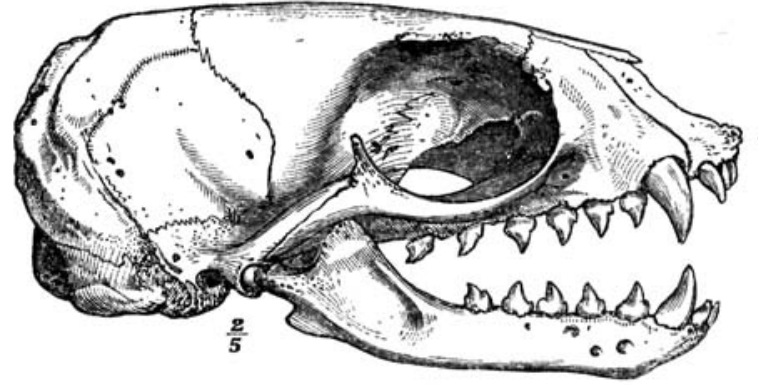

Gypsophoca tropicalis. Auckland Island.

Fig. 6.

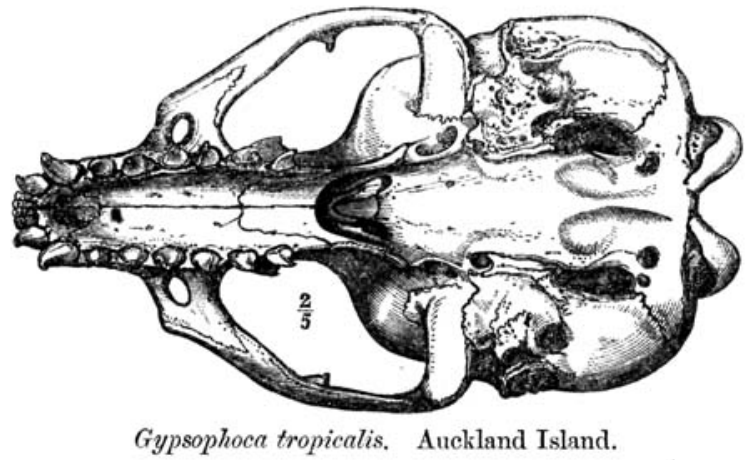

Dr. Peters, in the 'Monatsbericht,' 1866, p. 276, t. 2, describes and figures a skull from Juan Fernandez, on the west coast of America, which he received from Dr. Philippi, and founded on it his genus Arctophoca, calling it $A$. philippii.

This skull of $A$. philippii, from the large size and peculiar form of the brain-cavity, and the peculiarities of its underside (especially its large foramen), agrees with the skull from North Australia in the British Museum which I have called Gypsophoca tropicalis; but it is described and figured as only having five grinders on each side of the upper jaw, and Dr. Peters founds his characters on this peculiarity. I believe that the skull will be found to have lost the small upper hinder grinders, for which there is space at the hinder end of the 
alveolar edge. The skull has the fifth grinder behind the back edge of the front part of the zygomatic arch. The only Seals that I know that have the teeth in this position have six grinders in the upper jaw; and they, like this genus, all have triangular-shaped grinders and abundant under-fur.

Dr. Peters in his second paper on Eared Seals, 'Monatsbericht,' 1866, p. 671, enlarges his subgenus Arctophoca, and also refers to it Otaria falklandica of Shaw and Burmeister, which he says is my Otaria nigrescens, from the unpublished figure of the skull of it which I gave him, and which is a species of my restricted genus Arctocephalus, which has only the sixth upper tooth behind the front of the zygomatic arch.

Dr. Philippi sent a description and figure of a skull that he had received from the island of Masafuera, on the west coast of South America, which is published by Dr. Peters in the 'Monatsbericht' for 1871, p. 588, t. 1, 2, and which he calls Arctophoca argentata. This skull wants the hinder part of the brain-case, has six grinders in its upper jaw, and is in every respect very like the skull of Gypsophoca tropicalis and the Arctophoca philippii from Juan Fernandez. It chiefly differs from the figure of the latter skull, as Dr. Philippi shows in his plate, in the hinder portion of it being narrower, and the condyles much shorter or rather narrower.

These three skulls appear to me to belong to one group ; but whether they are three distinct species (two from the west coast of South America, and one from North Australia) I will not attempt to determine, as I have only seen the skins and skull of the one from the latter region; but they are all Fur-Seals and may be distinct.

Dr. Philippi proposes to enlarge the genus Arctophoca, and refers to it four species, which he thus characterizes :-

" 1. Arctophoca falklandica, Shaw, Gray, Burmeister. Grau, mit blas rother Unterwolle. Atlantischer Océan.

“2. A. nigrescens, Gray. Schwärzlich, mit dunkel rostrother Unterwolle. Atlantischer Ocean.

"3. A. argentata, Philippi. Grau, mit blas rother Unterwolle. Stiller Ocean.

"4. A. philippii, Peters. Schwärzlich, mit dunkel rostrother Unterwolle. Stiller Ocean."

If $A$. falklandica is my Arctocephalus falklandica, I have never seen its skull and do not know the position of its teeth.

$A$. nigrescens has the sixth upper grinder behind the back edge of the zygomatic arch, and belongs to my restricted genus Arctocephalus, in common with $A$. antarctica of the Cape, which is F. Cuvier's type of the genus, and $A$. cinereus of Quoy and Gaimard, of New Holland and New Zealand. A. argentata and $A$. philippii have the fifth and sixth upper grinders behind the back edge of the zygomatic arch, and, I believe, are both referable to the genus Gypsophoca.

The figures of the skulls of Otaria philippii and of Otaria argentata have the front edge of the hinder aperture of the nostrils with a triangular slit in the middle; the young skull of Gypsophoca tropicalis has it truncated and entire; but this part, as I have 
already observed, is liable to be imperfect in this respect in many species.

'l'emminck, in the 'Fauna Japonica,' makes some observations on the Eared Seals, and shows the inaccuracies of his predecessors. He describes one species, Otaria stelleri, and observes that the plate of the entire animal was drawn from a living animal in Japan.

It is very unlike the living animal of the family figured by Forster and that now aljve in the Zoological Society's Gardens. The fins look much more as if they were from a stuffed specimen made by a man who never saw a living Sea-bear. He figures the skeleton and three skulls as different ages of the same species, calling one (t. 22. f. 1, 2) from a very old, the second (t. 22. f. 3,4 ) from an adult, and the third (t. 22. f. 5, 6) from a middle-aged specimen-I suppose, all from Japan; but I do not see it so stated. The first two have only five upper grinders and very differently shaped beads; the third has six upper grinders and is a Gypsophoca. No species has been described from the North Pacific; and it may be a new species yet undiscovered, as all the other species come from the other side of the equator.

I should, judging from the figures, regard them as belonging to two, if not three, distinct species, and the whole theory of their being different ages of the same species as a mistake arising from not studying the growth of the teeth in these animals.

The skeleton of $O$. stelleri (t. 23) is taken from the same specimen as the skull which he says is of a very aged individual (t. 21.f. 1, 2), and is most probably the adult of Zalophus gillespii. Skull, figs. 3 and 4, may be the young of the same species; but, unfortunately, the underside is not figured of any of these skulls, so as to show the position of the teeth in connexion with the zygoma; and figures 5 and 6 are evidently Gypsophoca, as above stated.

\section{Note on Hyla punctata and Hyla rhodoporus. By Dr. A. Günther.}

[Received April 24, 1872.]

Hyla punctata was named by Schneider in the year 1799 (Hist. Amph. i. p. 170) and described thus :-

"Colorem griseum albidum distinguunt puncta nivea, sine ordine sparsa, inter oculos ot per totum dorsum; tania etiam nivea dorsum utrinque cingit, $a b$ oculis ducta supra aures usque ad femora."

This characteristic white band, similar to the lateral glandular fold of a Hylorana, is also mentioned by all following authors who had really examined examples of this Tree-frog : it is distinctly described and figured by Spix (1825, Spec. Nov. p. 37, tab. 9. fig. 4, Hyla 





variolosa), by Gravenhorst (1829, Delic. p. 30, tab. 6. fig. 2), by Duméril (1841, Erpét. Génér. viii. p. 553), by Burmeister (1856, Erlaeuterungen \&c. p. 104), and was finally observed by myself in two wellpreserved examples, one from Bahia (Dr. Wucherer, 1864) and the other, possibly, from Surinam (Museum Van Lidth de Jeude, 1866), which I accordingly named Hyla punctata of Schneider, and placed in the British-Museum collection with this name. Moreover these specimens were distinguished by a comparatively small tympanum of the size indicated by Duméril.

The typical example of Hyla rhodoporus (Proc. Zool. Soc. 1868, p. 488, pl. 37. fig. 4) from the Upper Amazons differed by lacking the white lateral band, and by having the tympanum larger; and even now, after six years' immersion in spirit, no white spots on the back have become visible. From a comparison of this specimen with the one from Bahia, one could scarcely believe in their specific identity.

Nevertheless I am now inclined to regard them as being of the same species. Having had my attention drawn to this point by Prof. Peters's note in Monatsber. Ak. Berlin, 1871, p. 403, I have reexamined our examples, the number of which has been increased to six; and although there is not one among them which agrees with $H$. rhodoporus in coloration, some approach it as regards general form and size of the tympanum; and I agree with Prof. Peters that, with our present materials, the specific distinctness of the two forms cannot be maintained.

Finally I may remark that Hyla papillaris, Spix, Spec. Nov. p. 34, tab. 8. fig. 2, may represent also a Iyla punctata without lateral bands.

6. On the Species of Quadrumana collected by Mr. Buckley in Ecuador. By P. L. Sclater, M.A., Ph.D., F.R.S., Secretary to the Society.

[Received May 1, 1872.]

(Plate LIV.)

When Mr. L. Fraser returned from Ecuador in 1860 he informed me of the existence of a large Monkey in the valleys of Western Ecuador, of which he had not been able to obtain specimens. I beard of this fact with much interest, as, although I had paid much attention to the distribution of the American Quadrumana, I was not aware of any species having been then recorded from any part of Western Ecuador, and I felt sure that the Monkey observed by Mr. Fraser, when obtained, would turn out to be a new or little-known species.

Mr. Edward Gerrard, Jun., having kindly allowed me to examine 
the skins of the Monkeys obtained by Mr. Buckley during his recent expedition to Ecuador, I have been able to ascertain what the species of Monkey observed, but not obtained, by Mr. Fraser was. 'Though not undescribed, it turns out to be a rare species, the Ateles fusciceps of Dr. Gray.

The species was so named in manuscript by $\mathrm{Mr}$ Fraser in 1845, when engaged in preparing a catalogue of this Society's former collection. The typical specimen having passed into the British $\mathbf{M u}-$ seum, was first described by Dr. Gray, in the 'Proceedings' of this Society for 1865, p. 733.

Ateles fusciceps was the only species of Monkey obtained by Mr. Buckley in Transandean Ecuador, although a second species, probably a Mycetes, was observed. From the neighbourhood of Macas, on this side of the Andes, Mr. Buckley has brought skins of five other species-namely, Mycetes seniculus, Lagothrix infumata, Pithecia monachus, Nyctipithecus lemurinus, and Saimaris sciurea.

All these, however, are already known as inhabitants of Upper Amazonia, and no doubt ascend the upper branches of the main stream so far as they meet with a congenial country.

Ateles fusciceps, of which I now exhibit the flat skin obtained by Mr. Buckley, and a drawing prepared from it (Plate LIV.), is a very well-marked species of this genus, readily known by its thick black fur and deep coffee-brown crown.

The hairs of the back have brownish tips. The skin measures 20 inches from the nose to the base of the tail, the tail 26 inches.

There appear to be no traces of a thumb on the fore limbs.

7. On the Skeleton of Todus, with Remarks as to its Allies. By Dr. James Murie, F.L.S. \&c. (Communicated by Professor Alfred Newton, F.R.S., V.P.)

[Received May 3, 1872.]

(Plate LV.)

When working at my memoir "On the Anatomy of the Kingfishers" I regretted much not having any specimen of Tody at my command, nor even a skeleton to compare with that of Ispidina, to which Todus in its external aspects bears resemblance. Thus placed, I had to confine my osteological remarks to the assertions of others concerning Todus, instead of basing them on my own observations and comparisons side by side, which I should have preferred.

Lately, Professor Alfred Newton has most kindly put at my disposal a skeleton, which I eagerly avail myself of, to make good in part my deficiency respecting this interesting genus.

Unfortunately the species and sex of the bird are not known; but, as the donor observes to me in his note, "the osteology of any one 




C. Berveasx inth. 
will stand for all," implying thereby the main features of the type.

I had proceeded in describing this skeleton, and elicited its probable relations, but upon one point doubted if my interpretation was correct. On consulting my friend Mr. Parker, to fortify or modify my opinion thereon, I fell in luck's way ; for, besides discussing the moot question, he put in my hands a good skeleton of the Green Tody, T. viridis, authenticated by Mr. Osbert Salvin, the original possessor. This increased material happily enables me to substantiate characters doubtless generic.

My text, in its detail, and the illustrations apply specially to Prof. Newton's specimen; but they agree so closely with the undoubted $T$. viridis, that $I$ have not required to alter or amend statements appertainiug to the former.

Under the subfamily Todina, Mr. Eyton* enumerates a few of the salient osteological distinctions of the Green Tody ( $T$. viridis), which I here quote in full :- " Cranium similar in shape to Merops; the maxillaries much flattened, covering the roof of the mouth for nearly one half the length of the cranium; impression for the masseter muscles very slight; a deep impression at the base of the nasal bones, from which a ridge proceeds over the top of the bill. Palatine bones similar in shape to Merops. Interarticular bones long, bent backwards in the middle. Sternum, pelvis, and other bones also similar."

His illustrations comprise a profile of the skeleton $\uparrow$ and under view of the sternum $\neq$, both of the natural size; and, besides, a somewhat enlarged sketch of portion of the palatal region \$. The small size of the figures mar considerably their usefulness for purposes of comparison. His analysis of osseous configuration, good in its way as a limited diagnosis of the genus, is, notwithstanding, imperfect when one attempts to gather the threads of structural relationship which the skeleton bears to divers others of the feathered tribe. These words are not to be interpreted as a wish to cavil with the labours of the said author. Rather, to Mr. Eyton's credit, be it said that he has been one of the few English ornithologists who have thoroughly appreciated the dominant stamp of characters impressed on avine skeletons, as is the case in other groups of the Vertebrata. His valuable volume, indeed, may be likened to a strong outpost commanding the flank of the enemy, and which I have the advantage of using as a basis of further operations, in sending a raking fire towards the centre.

Cuvier does not seem to have examined the anatomy of the genus Todus, his inference as to its position being deduced from the figure of the bill and structure of the feet. Within recent times another French comparative anatomist of some eminence, M. Êmile Blanchard $\|$, has described and figured the sternum of $T$. viridis. His opinions regarding it $I$ shall again have occasion to refer to.

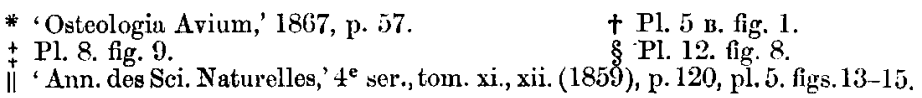


This is all 1 find which has been done towards elucidation of the osseous organization of Todus, and justifies my portraiture of the separate bones. These I have most carefully sketched twice their natural size, to bring into relief those discriminating lineaments subdued and lost sight of in a diminutive skeleton.

\section{Of the Cranium and Mandible.}

The skull, on the side view, I should as lief compare to that of the Rose-cheeked Kingfisher (Ispidina picta), the Motmots (Momotus), or even the Spotted Flycatcher (Muscicapa grisola), as merely to that of the Bee-eaters (Merops). In fact, it is not too much to say that, pari passu, it has no mean resemblance to some of the Woodpeckers', Picus viridis for example ; but critical investigation shakes such hasty conception.

In profile, the hinder segment, or that containing the brain, is full, roundish, and high. The supraoccipital area, particularly, is unduly prominent; and beneath this the outline shelves sharply dowuwards and forwards. The vacuity of the orbit equals the long diameter of the cerebral region; and the beak (or præmaxillæ) has a length nearly corresponding with the two parts behind. In other words, the osseous beak occupies half the length of the skull, or, indeed, slightly over that. This coincides with Eyton's observation, but does not agree with the proportions extant in the Bee-eaters, Jacamars, and Hoopoes, where the præmaxilla is often twice the length of the remainder of the cranium.

Amongst most of the Kingfishers, the beak is greatly in excess of half the long axis of the skull, Ispidina picta in its proportions (likewise Momotus lessoni) coming nighest to what obtains in Todus. The basal plane of the skull, in the view now under consideration, is almost on a horizontal line, there being only a very slight indication of depression towards the tip of the præmaxillæ. The latter throughout are very shallow and low compared with the orbito-central regions. The nasal orifice attracts attention by its elongate magnitude. From the root of the beak the prefrontal region rises very abruptly, and continues by a steep inclination to the vertex, the highest part of the skull being almost vertical with the posterior margin of the orbit. The latter is large and somewhat triangularly outlined, the narrow truncate end being forwards.

The posterior or occipital aspect of the skull of the Tody is characterized by smooth plumpness, tendency to quadrature of figure, the corners being bluntly rounded, and by the node-like elevation of the supraoccipital. In these respects it assimilates to Ispidina among the Alcedinidæ-yet, withal, is trenchantly separate therefrom by several particulars, which I shall notice in speaking of the separate cranial bones.

The general rotundity of the occiput and very feeble squamous groove more stringently belong to Muscicapa, though Merops, Momotus, Eumomota, Galbula, and Picus all manifest the sume ten- 
dency, the temporal muscular groove, however, being much better marked in them.

The cranial contour of Todus examined from above answers better to Ispidina than to Halcyon, Dacelo, and the narrow-beaked genera of Kingfishers. The two former, however, are quite as distinct from each other as are the varied types of the Kingfishers among themselves. The chief feature which draws Todus, Iepidina, and Eumomota together is the moderate breadth of the præmaxillæ, these bones continuing of fair width forwards. But in Ispidina they terminate more acutely than in Todus and Eumomota; and in the former they possess an onter basal constriction absent in the two latter. The said constriction is not met with in the Laughing Kingfisher (Dacelo); but, again, its broad beak has a pyramidal shape entirely different from the very low convex form in the Tody and Eumomota. In Todus, as contrasted with Ispidina and Eumomota, the prefrontal region is proportionally narrower and longer; the lower corners of the lachrymals are placed at right angles to the long axis of the skull, and the cerebral division is wide compared with its fore-andaft length. In Merops, Upupa, and Galbula, and in a less degree in Momotus, the broad.based and sharp forward cut of the beak, the short, very wide prefrontal or interorbital breadth, with the production anteriorly of the postorbital margin, are the reverse of what obtains in Todus. Whilst the prefrontals are narrow in Muscicapa, as in Todus, yet, on the other hand, in the former the beak is short and triangular, and the cerebral region antero-posteriorly fuller than in the latter. Picus, according to the size of the species (in the case of the smaller most markedly), manifests an upper skullcontour of a very different pattern.

The inferior view or base of the skull of the Tody necessarily has an outline corresponding to its rertex ; but the facies of the pramaxillæ, palatines, pterygoids, sphenoid, \&c. involves material differences of the mid area. The spaces enclosed by the jugal rods are long and narrow; the posterior narial orifice trends well back, causing the pterygoids to meet at a wide angle; the foramen magnum comes into fall view; and the spheno-occipital region is, on the whole, inflated. The differences extant in allied forms $I$ shall allude to hereafter.

With regard to the dimensions of the skull, seeing I have given enlarged figures, I may in this place take note of a few of the measurements, of natural size :-Extreme length $1 \cdot 3$ inch; extreme breadth (that is, above the tympanic region) 0.45 inch; and greatest height the same, the skull resting on a flat surface; beak from anteorbital root to its tip 0.7 inch; width of the præmaxillæ at their junction with the jugals $0.3 \mathrm{inch}$, and at their middle about 0.2 inch.

In reviewing the component parts of the cranium I shall commence with that portion which of recent date has attracted most attention, I mean the palatal region.

In the dried skull of the Tody each palatal moiety presents posteriorly a somewhat triangular, or V-shaped, horizontal plate, the rearmost angle meeting the pterygoid. The anterior angles of the 
plate send forwards an external and an interual spicule. The former narrow bony bar passes over the under surface of the lachrymal, maxillary, and maxillo-palatine enlargement, and, widening in its course, reaches and becomes anchylosed with the præmaxilla. 'The latter internal spicule passes onwards parallel with the outer one, and proceeds to the mesial edge of the maxillo-palatine bone. It is truly osseous to opposite the lachrymal, and is continued by ligamentous or tendinous material, which bears close resemblance to bone in its dried condition. Thus a long oval gap is left between the anteroexternal and internal palatal processes. The maxillo-palatines are spongy, and of fair size. They approach close to one another, but do not meet in the middle line-a narrow fissure separating them, floored by the osseous nasal septum. The mesial groove shallows forwards, but is continued quite to the apex of the beak.

Fortunately for me, the base of the skull which $I$ received from Prof. Newton had the dried membranous structures in part remaining; and on moistening and clearing off these, I gained insight respecting the fresh condition of the soft tissues \&c. occupying the inferior palatal region. A membrane filled up the oval gap betwixt the anterior palatal processes; and a thin pellicle of the same partially extended over the inferior hollow of each maxillary, and connected the outer edge of the external palatal process with the exterior border of the præmaxilla.

On slightly depressing and elevating the beak, or simulating its probable natural movements in life, I observed that in the latter action the lips of the posterior nares approximated and all but closed the fissure, the side parts, meanwhile, being kept tense. The beak's depression produced the reverse, membranes and elastic osseous rods equally springing outwards so as to open elliptically the post-narial fissure.

During the latter action two rod-like tendons come into view, simulating the bifid vomer of the Woodpeckers; and there is also a deeper median muscular bundle, besides large palatine nerves, which fill the fissure betwixt the maxillo-palatines and thence run forwards. These tendino-muscular slips arise from the incurved margin of the palatebones, or what may correspond to the vomeric crest of human anatomy, and are inserted into the maxillo-palatines. They evidently are the homologues of the levator and circumflex or tensor palati muscles. The above arrangement is interesting; for it explains to me an incongruity in Prof. Huxley's account of the palate of the Picidæe. The pair of anterior ossicles described by him correspond to the tendinous rods in Todus, external to which in both forms are oval spaces, otherwise bony plates in most of the Coccygomorphæe.

Todus, in the contraction and rod-like character of the anterior portion of its horizontal palatal plates, and in the large oval spaces, differs from the Alcedinidæ, the Momotidæ, the Meropidæ, the Galbulidæ, and the Upupidæ, and contrariwise, in the said respects, assimilates to the structure found in the Muscicapidxe and some others of the Coracomorphæ. Among the above I believe the genus Eumo- 
mota exhibits a gradal disposition of the parts, which character is heightened by the oblique truncation and posterior spineless nature of the palatal plates, and the short pterygoid bars. But in this genus and in Momotus the maxillo-palatines are mesially adnate, whereas in the other Coccygomorphine groups compared the osseous nasal septum less or more separates them.

If we turn to the præmaxilln, or what constitutes the beak, and for obvious reasons examine its upper surface, we shall at once be able to differentiate it from the whole of the Alcedinidæ, and notice some points allying it to the Momotidæ and Meropidæ. In the former groups, without exception, the opposite bones rise high, and incline towards each other with a well-defined ridge, sharp or rounder as may be, and occasionally, as in Pelargopsis, with a decided culmen. In Todus there is a most marked flatness, the bones exhibiting but a very slight convexity in front of the wares, and that which divides these orifices is limited to a low narrow rod or spicular bar. The nostrils are each 0.3 inch long, straight, elliptical, and widely patulous; they are most like those of Dacelo as far as magnitude is concerned, but, even relative to it, by far greater, and descend within a trifle of the inferior premaxillary border. 'The oral surface of the præmaxillæ is uniformly flat, and the vascular sculpturing or furrows most delicate.

The descending branch of the nasal bone forms a small, obliquely set ridge, surmounting the superior maxillary bone, and barely distinguishable from it. The inner branch and the fillet anteriorly bounding the fronto-maxillary hinge are both very narrow. Todus is unlike the Alcedinidæ and Momotidæ, great and small, in the low narrow ledging of the latter parts, and particularly in the way in which the prefrontals impinge in a rounded abrupt manner. It is this which gives the deep impression at the base of the nasal bones alluded to by Mr. Eyton.

In the size and shape of the narial orifices, lowness of depth, and rounding of the upper surface of the præmaxillæ, Eumomota, Merops, and some species of Picus have a cast towards Todus; but the arch of their nasal bones, relatively, is by far stouter ; their præmaxillæ, again, are more bent at the tip than in it.

The flatness, or wide shallow concavity of the prefrontals, which obtains in most of the Kingfishers and Motmots, does not apply to Todus; where each moiety is convex, the sagittal suture alone being represented by a well-marked mesial furrow. The prefrontals altogether are narrow, thus giving little interorbital breadth, which is even more strongly pronounced by the smallness of the upright limb of each lachrymal, which abuts against the anterior outer margin. Moreover this disposition produces a shallower appearance in the supraorbital incision, which in reality is deeper and wider than in the Alcedinidæ. As I have intimated, the ascending frontals have a steeper gradient than in the latter group, and the postfrontal region is in consequence more elevated even than in Ispidina.

Differentiation of the prefrontals \&c. in some other groups I have alluded to in speaking of the skull's contour superiorly. 
The temporal groove is rery feebly impressed, as Eyton observes; and hence this and postfrontal promivence amplifies the cerebral breadth. The bulging, hemispherical supraoccipital and equally full squamo-mastoidal region, therefore, give both posterior and lateral magnitude of a kind different from that in the Alcedinidæ. In these last the squamal groove, lambdoidal definition and ridging, and the less widely separate exoccipital impressions exhibit a character which is deficient in the more rotund occiput of the Tody.

The basiocciput and so-called basitemporal in Todus are relatively short antero-posteriorly; but, on the contrary, the bones spread well out towards the tympanic fossa, giving breadth to the basal region. Each quadrate bone is short-limbed, and, as in Halcyon and Ispidina, descends little below the basal plane of the cranium; but it differs from them in so far that it does not laterally project beyond the parieto-temporal facies.

There are no basipterygoid processes. The pterygoid bars are short, and meet each other at a considerably wider angle than in most of the Kingfisher tribe-a condition, as I have already pointed out, approximating to what obtains among the Motmots.

Regarding the ocular cavity (the truncate-wedge contour which has already been spoken of), it possesses an uncommonly large interorbital space. An osseous interorbital septum, in fact, is all but absent. It may be a question whether the septal deficiency, and the membranous rather than osseous character of the alisphenoids, \&c., do not denote juvescence in our bird. Still, in other respects, the skeleton appears that of an adult; and I am the more convinced that this membranous condition is the natural one, as in Mr. Parker's undoubtedly full-grown specimen it is quite as notable as obtains in Prof. Newton's.

The postfrontal and zygomatic processes are short.

The lachrymal bone, of an L-shape, has an upper widish truncate limb, only a small portion of which is visible from the front, the greater part of the bone resting wedged in between the prefrontal and preethmoid peninsulæ. 'The lower limb is spongy at its root, and sends out a narrow process, which lies upon the jugal, and acts as a kind of fulcrum to it in the resilient movements of the beak.

The mandible is precisely $l$ inch long, 0.4 inch in transverse diameter to the outer edges of the articular facets; and the breadth of the bone, measured at the posterior end of the symphysis, from one external border to the other, is 0.15 inch. Great flatness throughout characterizes the mandible, the symphysial segment, as seen on side view, being almost of the same depth as the rami. In this respect it agrees most with Ispidina amongst such of the Kingfishers as have come under my notice. The rami are thus bar-like, each laterally very compressed, tolerably straight and slender. Of the articular ends of the bone, I need but mention that the internal angular process is relatively of goodly size, almost Passerine in length, shallow, and narrow-pointed, the postarticular eminence unusually well pronounced, though low and upturned.

The symphysis is 0.32 long, widely scooped superiorly, this con- 
cavity and the inferior convexity being slight. The tapering of the mandible is steady and constant from behind forwards, but with fair breadth at the symphysial end, and terminating rather bluntly.

I would call attention also to the fact (which I do not find noted by oruithologists), that the horny mandibular margins are minutely denticulate, or serrate, thus agreeing with what obtains in the Momotide.

\section{Spine, Ribs, Breast-bone, and Pelvis.}

With respect to the number of vertebral elements present in the spinal column, I cannot tabulate these with the precision which might be desired-partly on account of their diminutive fragile nature, and still more because of the usual indefiniteness between what strictly belongs to the dorsal, lumbar, and sacral regions. According to my reading of the case there are 12 cervical, 7 dorsal, 9 coalesced lumbosacral (and coccygeal), and 7 free caudal-in all, 35 .

I am uncertain whether the last cervical does not possess a riblet, whereby it ought to be regarded as belonging to the series of the back rather than those of the neck.

Each cervical answers well to what has been portrayed by me in the Laughing Kingfisher, Dacelo gigas, dimensions excepted, the inferior styliform process possibly being relatively longer.

The dorsals have long spinous processes. I reckon those dorsal vertebræ which have ribs, and whose bodies are not ankylosed. But there is besides a vertebra firmly adherent to the sacral series, wherefrom the last rib seems to spring - though, from the costal adherence to the ilium, there is a certain dubiousness attendant.

The ankylosis of the lumbo-sacrals is complete. There is no development of inferior spines; and the continuous superior spine is very low, and outspread at its middle. These vertebræ, following Professor Huxley's nomenclature*, include lumbar, sacral, and urosacral, or (his more recent definition + ) dorso-lumbar and sacral ; nevertheless 1 prefer using the terms applied by me among the Alcedinidæ.

Of ribs, 8 exist on either side-the hindermost one, as I have intimated, partly resting against the anterior end of the ilium.

The total number of vertebræ in Todus (35) is less than in any of the Kingfishers, where they range from 37 in Ispidina to 41 in Dacelo.

M. Blanchard's determination of the sternum, his three ontlines of that of $T$. viridis, and the illustrations of Eyton lighten my task. As the former author remarks, one is struck by its resemblance to those of the Kingfishers. The summary of its distinctive points are:-shortness with breadth, and the sternal plates convex; tentous external and internal xiphoid pedate processes, with four deep fissures; keel deepish, but moderately produced in front, its anterior margin very shallow-bayed, and a high upward-pointed rostrum, barely cleft at the point; deep coracoid gutters, and internal mesial

* "On the Classification of Birds," P.Z.S. 1867, pp. 419, 422.

$\uparrow$ 'Manual of the Anatomy of Vertebrated Animals,' p. 278. 
foramen; costal process large and elongate. As to the connecting girdle of bones, each coracoid exceeds the oblique sternal diameter (i. e. from coracoid groove to the middle xiphoid process) ; epicoracoid large; the furcula is very delicate, without hypocleidium; the upper end of the clavicle is not expanded, and has no precoracoid spur.

Notwithstanding what the French author says, the above features of the sternum of Todus cannot be predicated of all the Alcedinidæ, but some of them more especially belong to the Halcyoninæ. Not only in its small size, but also generally, Ispidina is sternally likest Todus: but even in it the likeness is not complete; for instance, in it the xiphoid processes are shorter and stouter, the keel advances more forwards, and with an almost straight anterior edge, and the furcula is stouter and has a large precoracoid process. Taken all in all, the sternum of Eumomota is uncommonly like that of Todus, only enlarged.

In the Bee-eaters (Merops) the keel is still longer, the rostrum broad. The Jacamars (Galbula), with xiphoids not unlike the Tody's, have a much shorter rostrum; while in the Barbets (Capito and Megalaima) it becomes unusually elongate, as does the internal xiphoid bar.

Amongst the Flycatchers, and notably such as Todus has been considered affine to, a trenchant distinction obtains, there being in their sterna but two xiphoid notches; the rostrum not only is powerful, but terminally deeply eleft; the precoracoid is greatly expanded; and there is a hypocleidium.

I have demonstrated in my 'Anatomical Monograph of the Kingfishers' that their pelvis presents two extremes of configuration :- - one, Dacelo and the Halcyon group, where the praacetabular area is relatirely narrow through deflection of the ilia; the other, Ceryle and the Alcedine group, the reverse, or widish anteriorly, and, upon the whole, flat on the dorsum.

Todus rather draws towards the former, and presents modification from Ispidina in wanting a marginal iliac process in front of the acetabulum, and in having more sacral perforations and deeper dorsal grooves-characters diagnostic of Eumomota. The Muscicapidæ do not show any very separate type of pelvis from the Tody. The Meropidæ incline to the broad pelvic contour characterizing Ceryle and Alcedo.

\section{Bones of the Wing and Leg.}

The humerus is by no means diminutive, considering the small size of the bird, and as contrasted with the femur is large. Whilst there is a general likeness to the humerus of the Kingfishers, it yet presents easy shades of difference, conspicuous when the bones are laid alongside each other. The head relatively is more flattened antero-posteriorly, and is set more at a right angle to the shaft, giving a pouting character thereby. The shaft, moreover, has greater torsion, the same existing in Eumomota-a fact best appreciated when the small-sized humerus of Ispidina picta is submitted to comparison. 
I did not detect any special feature in the radius, ulna, and carpophalangeal bones, except as regards their relative lengths to each other.

Before speaking of the leg-bones themselves I shall advert to the limb as clothed with tegument.

There is a certain delicateness and tenuity in the foot; but the sole nevertheless manifests true syndactylism, inasmuch as two of the anterior toes, third and fourth digits, are closely united to about the proximal ends of their tertiary phalanges. On the dorsum of the font a sulcus runs a little way further back, but is narrow and not deeply cleft. The fission between the second and third toes is greater, their union reaching to the near end of their second phalanges. The hind toe in its ordinary position appears to be set obliquely inwards and backwards from the root of the second-its natural inclination, as far as I could make out, being fully as much in the former as the latter direction. This fact is hardly so forcibly pronounced in Plate LV. fig. 7 as it ought to be, in consequence of my desiring to show the papillary padding.

In this specimen the respective sizes of the free portions of the toes, including claws, were, in decimal parts of an inch:-hallux 0.28 , second toe $0 \cdot 17$, third $0 \cdot 2$, fourth $0 \cdot 16$; from the base of the hallux to the fork between second and third toes $0 \cdot 13$, and from the former point to the next cleft 0.22 inch, the latter therefore giving the extreme area of syndactylism.

As regards the tarsus, it is smooth and naked, a tendency to transverse wrinkling existing quite at the lower end and in front. The toes superiorly are clothed with subequal-sized quadriform scales, there being thirteen or fourteen on the middle anterior digit. A similar kind of tegument covers the sole; only the scales there are more circular and of a papillary character. The claws are laterally compressed with only moderate curvature.

I may pass over the femur with a mere word as to its very moderate strength and size. Regarding the tibia, its absolute length rather than stoutness is noteworthy ; and this applies still more to the tarsometatarse. There does not appear to be an osseous bridge connecting the inferior condyles of the tibia posteriorly, as in Dacelo, the tendons being confined by transverse ligamentous structure. The filbula, as usual, is short and spicular, but with a well-defined knobby head.

The grand limb-distinction between Todus and the whole of the Alccdinidæ consists in the former possessing a long tarsal segmenta feature which excludes it from the latter group, and retains it rather with the Muscicapidæ. In T. viridis it is of nearly equal dimensions with the tibia.

There is a slight grooving of the shaft anteriorly and superiorly; but posteriorly the scooping for tendons \& . is much deeper. The articular heads together present an oval surface with an absence of the flank process which obtains in the Dacelonine: the central elevation is also feebly marked. The postero-calcaneal ridge, or hypotarsus, stands feebly out behind, is narrow, with a shallow dent

Proc. Zoox. Soc.-1872, No. XLIII. 
rather than a cleft, and a single foramen. Its distal or inferior end has trifid knuckles. The middle one is the largest, and a very trifle longer than the lateral ones, whilst its fissure is the deepest; so that in the inferior view there appear four condyloid eminences, and a fifth, counting the metatarsal element. The latter metatarsal piece of the tarso-metatarsus is relatively of fair size.

In small forms such as that $I$ am dealing with, where there is great difficulty in instituting accurate comparisons with other skeletons, oftentimes but partially cleaned, the proportional lengths of the segments acquire paramount importance. 'The Tables I have constructed subserve better than lengthened verbal comparisons. I regret the want of a diminutive Motmot skeleton. I could have added a series of measurements and their proportions of the limbs of Merops, Galbula, \&c., in my possession, but believe the genera now given sufficient for my purpose.

1. Absolute lengths of the long bones of the extremities, in decimals of an inch, in Todus and some of its supposed allies.

\begin{tabular}{|c|c|c|c|c|c|c|}
\hline \multicolumn{7}{|c|}{ Wing. } \\
\hline & Humerus. & Ulna. & Radius. & $\begin{array}{l}\text { Meta- } \\
\text { carpus. }\end{array}$ & $\begin{array}{c}\text { Mid } \\
\text { phalanges }\end{array}$ & $\begin{array}{l}\text { Extreme } \\
\text { length. }\end{array}$ \\
\hline $\begin{array}{l}\text { Todus (viridis) } \\
\text { Ispidina picta } \\
\text { Momotus brasiliensis } \\
\text { Eurylaimus nasutus } \\
\text { Muscicapa grisola .... }\end{array}$ & $\begin{array}{l}0 \cdot 6 \\
0 \cdot 7 \\
1 \cdot 6 \\
1 \cdot 05 \\
0.65\end{array}$ & $\begin{array}{l}0.7 \\
0.9 \\
1.7 \\
1.25 \\
0.8\end{array}$ & $\begin{array}{l}0.7 \\
0.85 \\
\cdots \cdots \\
\cdots \cdots \\
\cdots \cdots\end{array}$ & $\begin{array}{l}0.3 \\
0.3 \\
0.7 \\
0.55 \\
0.4\end{array}$ & $\begin{array}{l}0 \cdot 2 \\
0 \cdot 25 \\
\\
0 \cdot 5 \\
0 \cdot 3\end{array}$ & $\begin{array}{l}1 \cdot 8 \\
2 \cdot 15 \\
\\
3 \cdot 35 \\
2 \cdot 15\end{array}$ \\
\hline \multicolumn{7}{|c|}{ LEG. } \\
\hline & Femur. & Tibia. & Fibula. & $\begin{array}{c}\text { Tarso- } \\
\text { metatarse. }\end{array}$ & $\begin{array}{r}\text { Mid-toe } \\
\text { phalanges }\end{array}$ & $\begin{array}{l}\text { Extreme } \\
\text { length. }\end{array}$ \\
\hline $\begin{array}{l}\text { Todus (viridis) ...... } \\
\text { Ispidina picta } \\
\text { Momotus brasiliensis } \\
\text { Eurylaimus nasutus } \\
\text { Muscicapa grisola ... }\end{array}$ & $\begin{array}{l}0.42 \\
0.5 \\
\ldots \ldots \\
0.9 \\
0.55\end{array}$ & $\begin{array}{l}0.68 \\
0.8 \\
1.8 \\
1 \cdot 4 \\
0.9\end{array}$ & $\begin{array}{l}0 \cdot 27 \\
\cdots \cdots \\
\cdots \cdots \\
\ldots \ldots . . \\
\cdots \cdots\end{array}$ & $\begin{array}{l}0.55 \\
0 \cdot 3 \\
1.2 \\
1 \cdot 0 \\
0.6\end{array}$ & $\begin{array}{l}0.45 \\
0.4 \\
\\
0 \cdot 7 \\
0.45\end{array}$ & $\begin{array}{l}2 \cdot 3 \\
2 \cdot 0 \\
4 \cdot 0 \\
2 \cdot 5\end{array}$ \\
\hline
\end{tabular}

The mode of measurement of the above is the same I have adopted in the Kingfishers (l.c. p. 53), where I state:- "In estimating the extreme length of the wing the radius has been excluded, and the sum of the other bones added together to obtain the approximate results. With the exclusion of the fibula the leg's length has been similarly reckoned. Concerning the ulna's long diameter the olecranon process has not been included, nor has the depending outer process of the metatarsus been taken into account. These extra processes, so to speak, exceed the actual jointed leverage of the individual 
pieces composing each limb, and hence are omitted to ensure correspondence in the calculations of the relative length of the leg."

2. Proportions of the wing-bones to each other.

\begin{tabular}{|c|c|c|c|}
\hline & $\begin{array}{l}\text { Uina to } \\
\text { humerus, } \\
\text { latter } \\
=100\end{array}$ & $\begin{array}{l}\text { Metacarpus } \\
\text { to humerus, } \\
\text { latter }=100 \text {. }\end{array}$ & $\begin{array}{l}\text { Mid digit } \\
\text { to humerus, } \\
\text { latter }=100 \text {. }\end{array}$ \\
\hline  & $\begin{array}{l}116 \\
1.28 \\
109 \\
119 \\
123\end{array}$ & $\begin{array}{l}50 \\
43 \\
43 \\
52 \\
61\end{array}$ & $\begin{array}{l}33 \\
35 \\
47 \\
46\end{array}$ \\
\hline
\end{tabular}

3. Proportions of the leg-bones to each other.

\begin{tabular}{|c|c|c|c|}
\hline & $\begin{array}{l}\text { Tibia to } \\
\text { femur, } \\
\text { latter } \\
=100\end{array}$ & $\begin{array}{l}\text { Tarso-meta- } \\
\text { tarse to } \\
\text { femur, latter } \\
\quad=100\end{array}$ & $\begin{array}{l}\text { Mid anterior } \\
\text { toe to femur, } \\
\text { latter }=100 \text {. }\end{array}$ \\
\hline 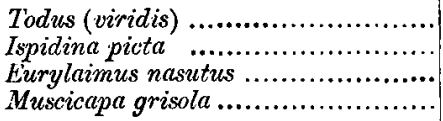 & $\begin{array}{l}162 \\
160 \\
155 \\
163\end{array}$ & $\begin{array}{r}131 \\
60 \\
111 \\
109\end{array}$ & $\begin{array}{r}107 \\
80 \\
77 \\
81\end{array}$ \\
\hline
\end{tabular}

4. Relations of bone-segments to the entire length of the wing.

\begin{tabular}{|l|c|c|c|c|}
\hline & $\begin{array}{c}\text { Wing =100, } \\
\text { proportionate } \\
\text { length of hu- } \\
\text { merus to it. }\end{array}$ & $\begin{array}{c}\text { Wing =100, } \\
\text { proportionate } \\
\text { length of } \\
\text { ulna to it. }\end{array}$ & $\begin{array}{c}\text { Wing =100, } \\
\text { proportionate } \\
\text { length of me- } \\
\text { tacarpus to it. }\end{array}$ & $\begin{array}{c}\text { Wing =100, } \\
\text { proportionate } \\
\text { length of mid } \\
\text { digit to it. }\end{array}$ \\
\hline Todus (viridis) ...... & 33 & 39 & 16 & 11 \\
Ispidina picta ..... & 32 & 42 & 13 & 11 \\
Eurylaimus nasutus & 31 & 37 & 16 & 15 \\
Muscicapa grisola... & 30 & 37 & 18 & 14 \\
\hline
\end{tabular}

\section{Relations of bone-segments to the entire length of the leg.}

\begin{tabular}{|c|c|c|c|c|}
\hline & $\begin{array}{c}\text { Leg }=100, \\
\text { proportion of } \\
\text { femur to it. }\end{array}$ & $\begin{array}{c}\text { Leg }=100, \\
\text { proportion of } \\
\text { tibia to it. }\end{array}$ & $\begin{array}{c}\text { Leg =100, } \\
\text { proportion of } \\
\text { tarso-meta- } \\
\text { tarse to it. }\end{array}$ & $\begin{array}{c}\text { Leg }=100, \\
\text { proportion of } \\
\text { ant. mid toe } \\
\text { to it. }\end{array}$ \\
\hline Todus (viridis) ...... & 18 & 29 & 24 & 19 \\
Ispidina picta ..... & 25 & 40 & 15 & 20 \\
Eurylaimus nasutus & 22 & 35 & 25 & 17 \\
Muscicapa grisola... & 22 & 36 & 24 & 18 \\
\hline
\end{tabular}


6. Relative proportions of the several segments of the wing to their homologues of the leg, and of the one entire extremity to the other.

\begin{tabular}{|l|c|c|c|c|c|}
\hline & $\begin{array}{c}\text { Humerus } \\
=100, \text { pro- } \\
\text { portion of } \\
\text { femur to } \\
\text { it. }\end{array}$ & $\begin{array}{c}\text { Ulna }= \\
100, \text { pro- } \\
\text { portion of } \\
\text { tibia to it. }\end{array}$ & $\begin{array}{c}\text { Metacarpus } \\
=100, \text { pro- } \\
\text { portion of } \\
\text { tarso-meta- } \\
\text { tarse to it. }\end{array}$ & $\begin{array}{c}\text { Mid digit } \\
\text { wing }=100, \\
\text { of mid antion } \\
\text { rior toe to it. }\end{array}$ & $\begin{array}{c}\text { Wing }= \\
100, \text { pro- } \\
\text { portionate } \\
\text { length of } \\
\text { leg to it. }\end{array}$ \\
\hline Todus (viridis) ...... & 70 & 97 & 183 & 225 & 128 \\
Ispidina picta ..... & 71 & 87 & 100 & 160 & 93 \\
Momotus brasiliensis & $\ldots$ & 102 & 171 & 140 & 116 \\
Eurylaimus nasutus & 86 & 112 & 182 & 140 & 116 \\
Muscicapa grisola & 85 & 112 & 150 & 150 & \\
\hline
\end{tabular}

Excepting in shortening of wing-digit, an Ispidine character, Table 2 demonstrates that Todus exhibits proportions of individual arm-bones likest the Flycatchers.

As to the wing-segments, and their reference to that extremity as a whole (Table 4), the characters throughout are much akin, the elongation of the ulna of Ispidina being a trifle in excess of its brethren the Kingfishers.

Among the leg-bones one to the other (Table 3) the difference of tibia to femur is not so manifest; but in tarso-metatarse to femur there is a wide distinction, the Tody even far surpassing Eurylaimus. It is noticeable in the former also that the middle toe acquires undue preponderance. This abnormal elongation is apparently modified when the comparison or the length of the digit with the proportional height of the entire leg is taken into account.

Thus collated (vide Table 5), the tarso-metatarse of Todus still retains a magnitude corresponding to what obtains among the Flycatchers, but, contrariwise, a decrease of femoral length even below these latter and all the genera of Coccygomorphæ examined by me. In the last set of calculations ('Table 6), humerus versus femur, it is shown that the Tody and Kingfisher are partners. The same well nigh holds good in the proportion of the tibia to the ulna; and the Motmot comes betwixt the Tody and the Flycatcher. That peculiar feature of Todus, tarso-metatarsal length, is very conspicuous when collated with corresponding metacarpal size, and it becomes apparent that the Motmot and Tody embrace the Eurylaimidæ and Muscicapidæ, and disjoin themselves from the whole of the Kingfishers ; for I must observe that Ispidina stands aloof from its tribe in the above respect.

The ratio of the entire length of the leg to the wing serves to point out that even the Muscicapidæ have it shorter than Todus; and I may further assert from my researches that not one of the Kingfishers comes near the former group in this peculiarity.

I am not oblivious to the fact that such arithmetical generalizations are founded on limited data; but they nevertheless explain several points which were a puzzle to me. The Rose-cheeked Kingfisher 
is most aberrant in some of its limb-dimensions, and so, indeed, are the Stork-billed Kingfishers; but these very abnormalities serve to smooth vexatious questions of consanguinity, and act as supports to the chain of affinities uniting other characters.

\section{Todus and its kindred.}

"Les Todiers sont de petits oiseaux d'Amérique, assez semblables aux Martins-pêcheurs pour la forme générale, et qui en ont aussi les pieds et le bec alongé, mais où ce bec est aplati horizontalement, obtus à son extrémité, le tarse plus élevé, et la queue moins courte."

Such was Cuvier's* notion of these birds, a judgment not acquiesced in by many subsequent writers. Among pure ornithologists, however, Vigors $\uparrow$ seems to have followed in the wake of Cuvier, and in his 'Fissirostres' places the 'Todidæ between the Caprimulgidæ and Halcyonide. Eurylaimus is his connecting link between the Tody and the Goatsuckers, though to Halcyon, according to him, there is more intimate resemblance.

Lesson $\ddagger$, it appears, believed in the genus having great approximation to the Kingfishers through Todyrhamphus, yet doubtfully disposes of it betwixt Platyrhynchus and Myiagra. The acute and original-minded Nitzsch $\S$, from his pterylographic studies, makes a group Todidæ, wherein Coracias, Merops, Prionites, Todus, and Galbula are respectively included as subdivisions. The Motmot and Tody are associated on account of having a spinal tract without a space. Temminck's $\|$ arrangement is as follows :-Rupicola, Pipra, Pardalotus, Todus, Platyrhynchus, Muscipeta, Muscicapa.

Bonaparte of gives a subtamily to the Todinæ, the genus Todus coming between Psaris and Todirostrum, the family of the Todies having position after the Cotingidæ and Eurylaimidæ. In Gray's 'Genera of Birds' Todus comes under the Coracidæ; this is followed by the 'Trogonidæ, and then the Alcedinidæ. In the same writer's recent 'Hand-List of Birds,' 186!, the grouping runs, Coracidæ, Eurylaimidæ, Todidæ, Momotidæ, 'Trogonidæ, Bucconidæ, Alcedinidæ, Meropidæ, and Galbulidæ. Another ornithologist, Mr. Swainson**, has devoted a volume to the Flycatchers, wherein Todus is assigned a nearly central position-Megalophus and Platyrhynchus coming on the one hand, Lepturus, Muscipeta, \&c. on the other. Todus, as Swainson takes it, is preeminently typical and a standing proof of the correctness of his ornithological circular system.

As a naturalist whose observations have been made amongst forest and glade, Mr. Wallace + t takes a high place. His conclusions are as

* Règne Animal.

+ Linn. Soc. Trans. (1822-3) vol. xiv. p. 431.

\$ Manuel d'Ornith. vol, i. p. 179 .

$\$$ 'Pterylographie,' and Iingl. ed. Ray. Soc. 1868 , p. 89.

II 'Manuel d'Ornithologie,' 2nd ed. (1820), part i. p. 65.

- 'Conspectus Generum A vium,' p. 182.

** 'Naturalist's Library,' Birds, vol. xiii.

t† Ann. \& Mag. of Nat. II ist., Sept. 1856, p. 200. In this masterly essay Mr. Wallace most logically discountenances Swainson's "circular arrangement" as untenable. 
undernoted:-_ "The little Todies of the W. Indies have also been usually classed as Fissirostres; but their moderately long and slender legs, short rounded wings, and their excessive activity on their feet are so totally opposed to the characters of every other member of that group that we think them far more naturally associated with such Flycatchers as Todirostrum and Megalophus."

M. E. Blanchard, to whom allusion has already been made, from his osteological research, says (l.c.p. 122):-“ “On trouvera dejà singulièrement justifiée l'opinion émise par Cuvier au sujet des affinités naturelles des Todiers." According to sternal characters he ranges the Kingfishers, Tody, Jacamars, and Bucco in succession. I may furthermore cite Mr. Eyton, who, in his 'Osteologia Avium,' under the family Alcedinidæ, places as subfamilies Alcedinæ, Halcyoninæ, Galbulinæ, Meropinæ, Todinæ, and Coracinæ in sequence. Lastly, Dr. Sclater in a curt notice*, seems to indorse Blanchard's view, whose figures of sterna he copies, when he says-"Todus is closely allied to Alcedo and still more to Momotus, its nearest living ally being certainly the diminutive Motmot called Hylomanes momotula." . Without expressing the reasons wherefore, he concludes"That the Todida should be constituted a family of the Coccygomorphæ, in the immediate neighbourhood of the Momotidæ." The connexion of these two, as I have noted, Nitzsch long ago advocated from their pterylosis; and they have since been placed side by side by Mr. George Gray.

It would seem, then, that where outward appearance has swayed, naturalists judged Todus as having alliance with the Flycatchers or the Motmots ; but where anatomical evidence has been relied on, the Kingfishers and Bee-eaters are the groups with which it carried family likeness. My own studies elicit a certain unanimity out of this cross fire of opinions.

Todus is inconsistent in several respects. The habits, food, and build or form are mainly those of the Muscicapidæ. The coloration partially belongs to that group, and partially leads to some of the Alcedinidx. The long slender tarsus, its scale-covering, and the figure of the wings associate it with the Flycatchers and such insectivorous birds; but the syndactylous disposition of the foot is rather that of the Kingfishers. The shape and the length of the bill does not quite justify such paternity ; for although it has been asserted to be truly Halcyonine, I regard it as sui generis-a kind of conıpromise with the last, tinctured wonderfully with Muscicapine, Momotine, Meropine, Galbuline, and Buccine tendencies. The rictal bristles, though short and weak, markedly take the genus away from the Kingfishers and betoken connexion with the Barbets and Flycatchers. The minutely serrate mandible correlates it to the Motmots. Regarding pterylosis, as we have mentioned, Nitzsch places it between the Motmots and Jacamars. But $I$ would observe that in the fact of there being only 19 remiges, we have a number belonging to Psaris, Platyrhynchus, and Tyrannus, instead of from 21 to 23 pertaining to the group wherv Todus is put by the German ornithologist. I own, on * 'Ibis,' April 1872, p. 179. 
the other hand, that the feather-tracts are not after the disposition of the Muscicapinæe.

When we come to test skeletal relations, the first question is whether it be $\mathbf{E g i t h o g n a t h o u s ~ o r ~ D e s m o g n a t h o u s ; ~ a n d ~ t o ~ t h e ~ l a t t e r ~}$ it must be assigned. This seemingly settles the matter as to Passerine kin ; yet as in externals, so internally there are ties denoting osteological development after the type of the Muscicapida rather than Alcedinidæ and allies. Such are the large vacuities in the horizontal palutal plates, the short inward set of the pterygnids, the large patent nares, the brain-elevation, the membranoid condition of the ali- and orbito-sphenoids, the non-ossification of the interorbital septum, the shape and set of the lachrymals, the occipital contour, the shallow squamoid groove, the vertebral numbers, the humeral torsion, the spineless anteiliac margin, the shape of hypotarsus, and, lastly, tarsal elongation. Though so numerous seem the discrepancies, they are nevertheless counterbalanced and overmatched by osteological organization assigning kindred to the Coccygomorphine group.

It results, then, from my investigation and a summing up of the labours of others that Todus is a Coccygomorph. Its nearest living allies undoubtedly are the Motmots and Kingtishers; but it presents such aberrance that it ought not to be ranked amongst either, but in proximity as a separate division of the Coccygomorphæ-the 'Todidæ, equivalent to the Momotide. As I interpret avine forms, a tithe only of which are kuown (for who can say what fossil remuants are yet to be dug up), we cannot be positive of the direct lineage that any abnormal group specially were derived from. Here I shall urge the remarkable ranifications affiliating the Tody with genera of the most diverse sorts-Momotus, Ispidina, Myoceyx, Alcyone, Muscicapa, Cymbirhynchus, Platyrhynchus, Merops, Galbula, Capito, \&c., all more or less, one might say, tainted with parent blood. This forces on me the conviction how difficult it is to divine from limited data the descent and nearest kindred of many of those so-called aberrant forms, be they Bird, Mammal, or Reptile; so that the vital stock and the modus operundi of differentiation are as yet hidden, which palæontology and the study of development may one day help us to unravel.

It may be presumed that Todus comes of Halcyonine lineage, though its organization places it in juxtaposition with the Motmots. It moreover offers structure so truly Passerine as to mask its more direct allies; and such exterior points deceived the older naturalists or were too strongly insisted on.

\section{The Todidæ.}

Coccygomorphs characterized by:-Naked oil-gland; feathers with diminutive aftershaft; spinal tract simple, dilated behind scapulæ; each moiety of ventral tract posteriurly tenuous, with wide pectoral and humeral branches. Tongue thin, tapering; stomach muscular; intestines short and with cæca. Right and left carotids; lower larynx simple, with a pair of muscles. Feet syndactyle; first 
toe reversed; claws short; tarso-metatarse very long; hypotarsus with one foramen. Sternum short, broad; four wide xiphoid clefts; upper end of furcula narrow, and no hypocleidium; epicoracoid large ; coracoid exceeding the oblique sternal diameter. Præmaxillæ long, wide, straight, and low ; nares elliptical, large ; a great interorbital space; brain-segment high and full; postfrontal and zygomatic processes short; maxillo-palatines large, spongy, with interrening cleft ; postpalatal processes absent ; and anterior, elongate, wide, horizontal palatal spaces obtain ; lachrymals spongy, without upper retrocurrent limb; basipterygoids none; pterygoids relatively short; mandible flat, symphysis large and broad; horny margins minutely toothed.

Habitat of typical and only known (?) geuus Todus, Tropical America.

\section{EXPLANATION OF PLATE LV.}

Separated skeleton of a species of Tody (Todus viridis), showing the most characteristic views of its osseous framework, twice their natural dimensions. All the segments, save the ribs and cervico-dorsal vertebræ, are represented.

Fig. 1. The skull from above.

Fig. 2. The inferior base of the same.

Fig. 3. A profile view of the cranium with the mandible.

Fig. 4. Occipital facies of the skull.

Fig. 5. Upper or oral surface of the mandible.

Fig. 6. The lachrymal bone of the left side, seen from behind.

Lettering applicable to the above:- n, nasal bone ; $l$, lachrymal ; mxp, maxillo. palatine; $m x$, maxillary ; $p t$, ptersgoid ; $q$, quadrate; $p$, palatal plate, $e$ being the external and $i$ the internal anterior palatal processes; ios, interorbital space; $p f$, postfrontal processes; $z$, zygomatic process.

Fig. 7. The sole and tarsus of the right foot, with the tegumentary covering. I, II, III, IV, the digits respectively.

Fig. 8. A front view of the bones of the same: $t m$, tarso-metatarse; $m$, metatarsal element.

Fig. 9. Posterior surface of the right humerus: $h$, an upper view of its head, and $c$, the inferior end or condylar aspect.

Fig. 10. Ulna $(u)$ and radius $(r)$.

Fig. 11. Metacarpus and phalanges, from in front of left wing: I, pollex; II, distal phalanges of second digit; $m^{2}, m^{2}$, partially united metacarpals.

Fig. 12. Left femur from behind.

Fig. 13. Right tibia $(t)$ and fibula $(f)$ from in front.

Fig. 14. Upper or proximal end of the tarso-metatarse.

Fig. 15. Lower or distal extremity of the same.

Fig. 16. Lateral aspect of the sternum and shoulder-girdle: $c$, costal process; $r$, rostrum.

Fig. 17. Inferior view of the same.

Fig. 18. Interior of the pelvis and under surface of the tail-vertebra.

Fig. 19. External pelvic side view.

Fig. 20. Dorsal aspect of the pelvis and termination of the spine. 